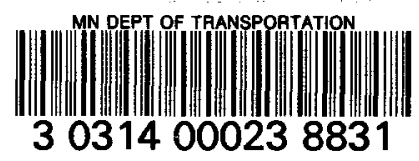

$\begin{gathered}\text { Summer } \\ \text { Rear }\end{gathered} 1999-05$
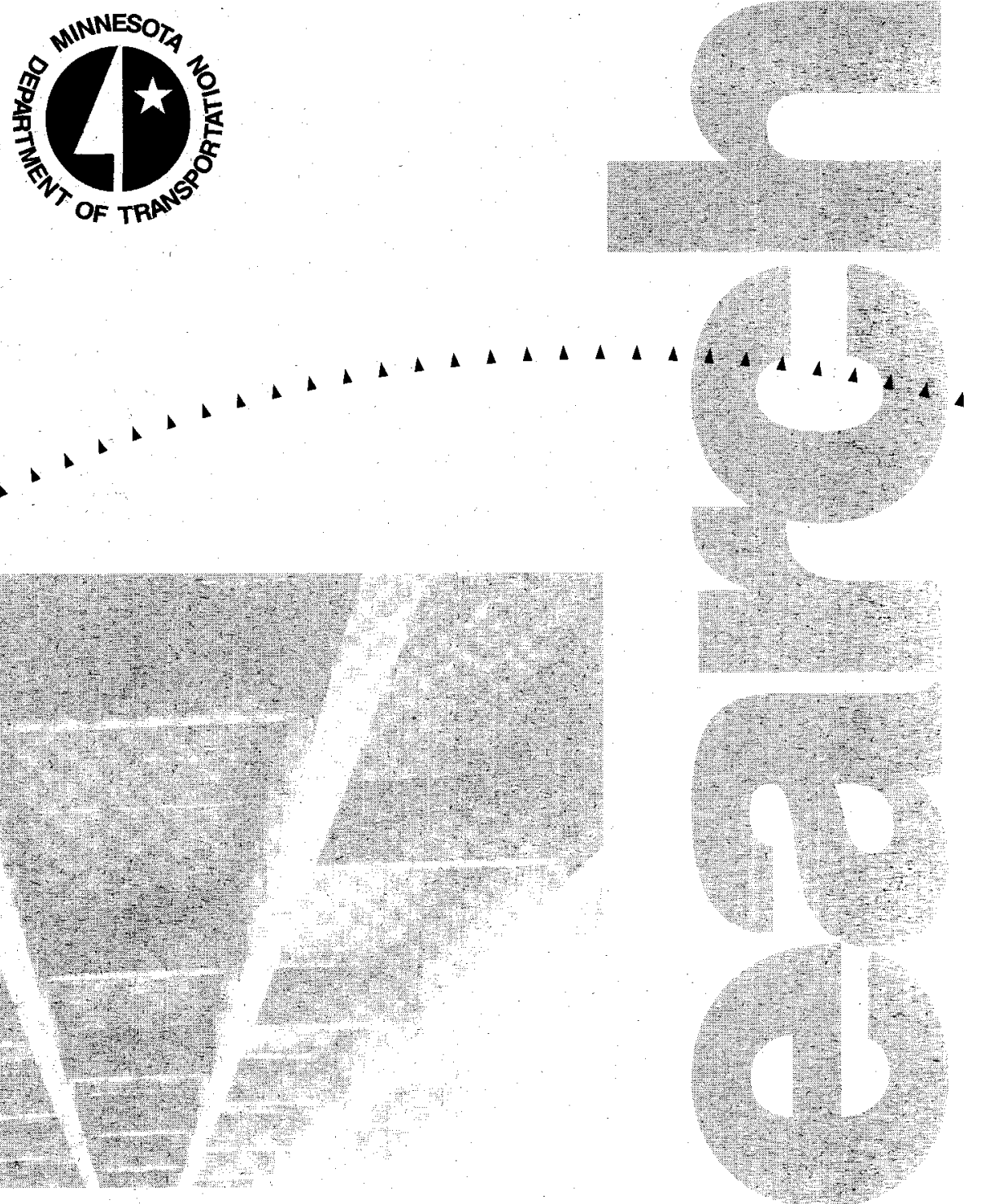

Tranverse Cracking

CTS

TG

325.6

In Concrete Bridge Decks

. T74

1999

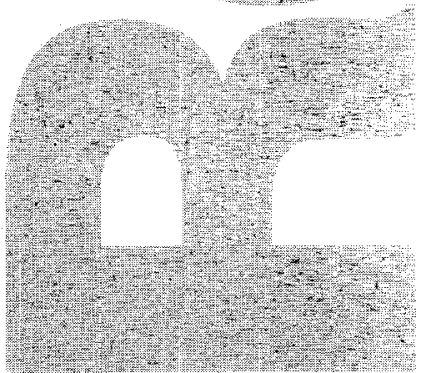





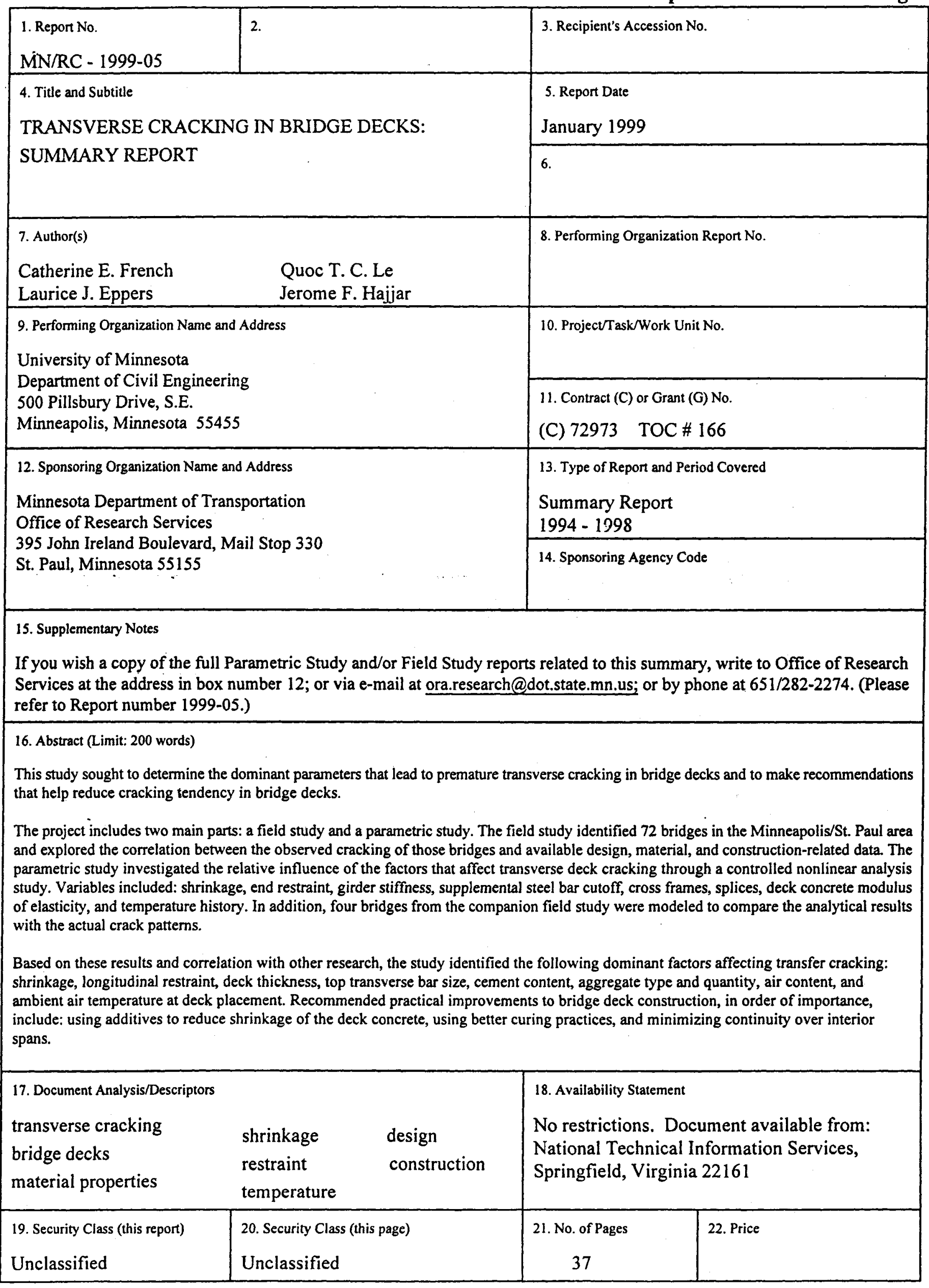





\title{
TRANSVERSE CRACKING IN BRIDGE DECKS
}

\author{
Summary Report
}

\author{
Prepared by: \\ Catherine E. French \\ Laurice J. Eppers \\ Quoc T. C. Le \\ Jerome F. Hajjar \\ Department of Civil Engineering \\ University of Minnesota \\ CivE, Civil Engineering Bldg. \\ 500 Pillsbury Drive, S.E. \\ Minneapolis, MN 55455
}

\section{January 1999}

\author{
Published by: \\ Minnesota Department of Transportation \\ Office of Research Services \\ Mail Stop 330 \\ 395 John Ireland Boulevard \\ St. Paul, MN 55155
}

This report represents the results of research conducted by the authors and does not necessarily reflect the views or policies of the Minnesota Department of Transportation or the Center for Transportation Studies. This report does not constitute a standard, specification or regulation. 



\section{ACKNOWLEDGMENTS}

This project was sponsored by the Minnesota Department of Transportation and the Center for Transportation Studies at the University of Minnesota. The authors gratefully acknowledge the project Technical Advisory Panel contact, Paul Kivisto, for his input and assistance. The authors also express appreciation to the Minnesota Department of Transportation personnel who provided bridge documentation from the Records Office (Central Files), the Materials Office, the Golden Valley Resident Office, the Mendota Resident Office, the Oakdale Resident Office, and the Eden Prairie Resident Office. Appreciation is also expressed to the undergraduate research assistants, Lara Semmens, Paul Sponholz, Samuel Rubenzer, and Jennifer Soderstrom, for their assistance in this research. The views expressed herein are those of the authors and do not necessarily reflect the views of the sponsors. 



\section{TABLE OF CONTENTS}

OBTRODUCTION




\section{LIST OF TABLES}

Table 1 Summary of dominant parameters affecting transverse cracking in concrete bridge decks

Table 2 Typical documentation presented per bridge [after (Eppers et al. 1998)] ...... 24

Table 3 UMN concrete bridge deck water and cement content data ........................ 26

Table 4 Parametric study of steel bridge girder (Base case: Bridge 62888) ............ 27

\section{LIST OF FIGURES}

Figure 1 Bridge No. 19882: Spans 1 and 2, showing cracking on bottom of deck [after (Eppers et al. 1998)]

Figure 2 Bridge No. 19882: Pier 1 at west edge of bridge deck [after (Eppers et al. 1998)]

Figure 3 Bridge No. 19882: Spans 2 and 3, showing east edge of bridge deck [after (Eppers et al. 1998)]

Figure 4 Bridge 19882 crack pattern [after (Eppers et al. 1998)] 32

Figure 5 Restraint coefficient beta (at midspan) vs condition: steel girder bridges 33

Figure 6 Spacing of top transverse reinforcing bars vs condition: steel girder bridges. 34

Figure 7 Air temperature at deck placement versus condition: prestressed girder bridges

Figure 8 Shrinkage curves: comparison between experimental curves and ACI 209 curve [after (Le et al. 1998)].

Figure 9 Bridge 62888 crack pattern [after (Le et al. 1998)] 37 


\section{EXECUTIVE SUMMARY}

Early transverse cracking in bridge decks in their positive moment region is a phenomenon experienced by a large number of states throughout the country. To investigate the causes and extent of the problem in the State of Minnesota, a two-phase research program was conducted by the University of Minnesota (UMN). The first phase of the study was a field investigation to determine the correlation between the observed cracking and available design, material, and construction-related data (Eppers et al. 1998). The second phase of the research comprised a laboratory shrinkage study and a parametric study. In the parametric study, a number of variables (e.g. material properties, girder properties, end restraints) were investigated analytically to determine their relative influence on transverse cracking in bridge decks (Le et. al. 1998).

The UMN field investigation included 72 bridges located in and around the Minneapolis/St. Paul metropolitan area (i.e., 34 composite simply-supported prestressed girder bridges, 34 composite continuous steel plate girder bridges, and 4 composite continuous rolled wide flange girder bridges). Crack patterns were documented and the bridges were given a condition rating based on transverse crack damage. Data was collected for each bridge and documented in a database for the parameters considered to be relevant to bridge deck cracking. Each parameter was compared to the UMN deck condition rating on two-dimensional graphs to determine the correlation with deck cracking tendency. Eppers et al. 1998 contains all bridge documentation for the 72 bridges observed. The documentation includes Field Observation Logs, photographic documentation, crack pattern drawings, and Parameter and Material Data Sheets.

Based on the results of the UMN field study and correlation of the data with other research, dominant factors in transverse bridge deck cracking were identified. Dominant design parameters included: longitudinal restraint, deck thickness, and top transverse bar size.

Dominant material-related parameters were: cement content, aggregate type and quantity, and air content. Ambient air temperature at deck placement was the only dominant construction related parameter discussed in detail herein. 
The shrinkage study was conducted on two Minnesota Department of Transportation (Mn/DOT) concrete bridge deck mix designs. One of the suspected reasons for increased transverse cracking observed in bridge decks used in the State of Minnesota was a change in the standard concrete mix design from what was termed a $3 \mathrm{Y}$ mix to a $3 \mathrm{X}$ mix. To reduce the occurrence of transverse cracking, Mn/DOT standard deck mix specifications returned to the $3 \mathrm{Y}$ mix in recent years. The UMN laboratory shrinkage study included characterization of the shrinkage characteristics of both types of mixes. The results indicated that there was not a significant difference in the free shrinkage observed for the $3 \mathrm{X}$ and $3 \mathrm{Y}$ mixes. However, both types of mixes were observed to exhibit substantially higher initial shrinkage rates relative to that predicted by ACI 209 [1]. This may be attributed to the different curing procedures employed by the ASTM standard versus those experienced in the field. The preponderance of cracks in both old and (especially) new bridges suggests that early bridge deck cracking was exasperated by these higher initial shrinkage rates, coupled with the additional parameters highlighted in the field and parametric studies.

To isolate the effects of individual parameters that have potential impact on transverse cracking in bridge decks, a computational parametric study was conducted using the program PBEAM. The program enabled time-dependent analyses of single-span steel or concrete girders made composite with the casting of a concrete deck. Nonlinear concrete constitutive properties were modeled, including cracking in tension, creep, shrinkage, and aging of the concrete deck and prestressed girders, and relaxation of the prestressing strands. To represent the boundary conditions of continuous steel girder bridges, supports were modeled as either fixed against rotation and horizontal and vertical translation (representing continuous spans), pinned (free to rotate), or roller (free to rotate and translate horizontally). These boundary conditions were meant to represent idealized extremes so as to bracket the results of more realistic boundary conditions.

The parametric study was conducted using prototype girders, with base cases modeled from two bridges chosen from among the inventory of 72 bridges investigated in the field study. One was a prestressed concrete bridge (Bridge 19042), and the other was a two-span continuous steel girder bridge (Bridge 62888). Starting with these base cases, a large number of nonlinear static analyses were conducted, varying key parameters. The variables considered for the prestressed girder 
bridge parametric study included: the timeline (relative times for strand tensioning, casting, strand release, and deck casting); and shrinkage properties (ACI 209 versus upper and lower bounds from the shrinkage study). The variables considered for the steel girder bridge parametric study included: end conditions; girder stiffness; cross frame, splice, and supplemental reinforcing bar locations; shrinkage properties; concrete modulus; and temperature differential due to heat of hydration.

The results of the parametric study correlated well, in a general sense, with the field study. To verify the results of the analytical parametric study more specifically, the prototype bridge results were compared with the observed behavior in the field. In the case of the prestressed girder bridge (19042), there was good agreement between the analyses and the bridge performance--no cracks were observed in the real bridge. Good agreement was also observed in the case of the two-span steel girder bridge (62888). Cracks were observed to develop near the roller, and increased crack concentrations occurred near the continuous end. The only discrepancy between the analyses and field observations was that cracks were also found near midspan in the analysis, which was not the case in the field. A third bridge was also investigated (19882) to compare the results of the analyses with a continuous steel girder bridge of three or more spans. In both the analysis and field observations, the interior span cracked uniformly throughout and the end span developed two primary cracks.

Based on this research, the following summary recommendations were made (the report contains more detailed recommendations):

- Reduce longitudinal restraint of the concrete deck. It is recommended to reduce deck continuity over interior supports on continuous girders, minimize girder restraint, and minimize shear connector restraint:

- Reduce concrete shrinkage through changes in the maximum cement content, water-cement ratio, minimum air content, maximum aggregate content, and improved curing.

- Thinner decks (6 1/2") were observed to result in increased cracking in the field study. 
- Use No. 5 (5/8" diameter) top transverse bars in concrete bridge decks on steel girders (bar size was not a significant factor for prestressed girder bridge decks).

- Reduce the effects of ambient air temperature by placeing concrete decks only where the ambient air temperature is above approximately $40^{\circ} \mathrm{F}$ to $45^{\circ} \mathrm{F}$ or is below approximately $85^{\circ}$ $\mathrm{F}$ to $90^{\circ} \mathrm{F}$. Also, avoid pouring concrete on days when there is a large temperature range. 


\section{INTRODUCTION}

Early transverse cracking in bridge decks is a phenomenon experienced by a large number of states throughout the country $(1-4)$. The transverse cracks result when the longitudinal tensile stresses exceed the concrete modulus of rupture. These cracks often initiate soon after the bridge deck is constructed due to restrained shrinkage. Field observations by state departments of transportation (DOT's) indicate transverse cracks are the most commonly occurring type of cracks in concrete bridge decks $(2,3)$. In an effort to increase deck service life, various modifications to standard bridge deck design have been made in the past 30 years, including: use of epoxy coated reinforcement, minimum cover of $76 \mathrm{~mm}$ (3"), minimum deck thickness of 230 $\mathrm{mm}$ (9"), and modifications to the concrete deck mix design. In spite of these modifications, transverse cracks have continued to appear. Current maintenance procedures (e.g., crack sealing, deck reoverlay, and reconstruction) are costly operations. Consequently, it is desirable to determine the factors that affect transverse cracking in bridge decks, and to develop recommendations to reduce or eliminate the cracks.

\section{OBJECTIVE}

This report summarizes a two-phase research program was conducted by the University of Minnesota (UMN) to investigate the causes and extent of transverse cracking in bridge decks within the State of Minnesota. The first phase of the research, described in detail in a report by Eppers et al. (5), was a field investigation of seventy-two bridges. The objective of this portion of the study was to determine the correlation between the observed cracking and available design, material, and construction-related data. A limitation of the field study was the inability to isolate individual parameters that affect transverse cracking in bridge decks because the cracks form (or do not form) in a real bridge due to a complicated combination or interaction of a number of variables.

The second phase of the research, described in detail in a report be Le et al. (6), comprised a shrinkage and a parametric study (6). For the shrinkage study, two types of concrete deck mixes were cast in the field and subsequently monitored in the laboratory to investigate their shrinkage 
characteristics with respect to time. The data were used to bound the concrete deck shrinkage characteristics used in the parametric study. The objective of the parametric study was to investigate the relative influence of the factors that affect transverse deck cracking through a controlled series of nonlinear finite element analyses. The parametric study overcame the limitation of the field study by enabling individual variations in parameters to determine their relative influence on the transverse cracking phenomenon. The variables included: end restraint, girder stiffness, cross frame location, splice location, deck supplemental steel bar cutoff length, deck concrete shrinkage characteristics and modulus of elasticity, and temperature history. Two base case bridges were used in the parametric study: a prestressed concrete (Bridge 19042) and steel girder (Bridge 62888) bridge. Following the parametric study, three bridges were modeled as accurately as possible to compare the analytical results to field observations. These bridges included the two used in the parametric study (Bridges 19042 and 62888) plus Bridge 19882 (continuous steel bridge with 3 or more spans). These three bridges were modeled using the actual available design, material, and construction information to correlate the analytical results with the actual crack patterns.

\section{BACKGROUND}

A large number of research investigations have focussed on the issue of transverse cracking in newly constructed bridge decks. Studies found to be most relevant to the current investigation are given in references $1-4$ and 7 . The research described in these references included: DOT agency surveys, analytical studies, laboratory shrinkage tests, laboratory restraint tests, field surveys, and concrete deck monitoring from deck pour until observed cracking. Major contributors to transverse cracking in bridge decks, as reported by these studies, included: concrete shrinkage, curing, temperature during the deck pour, and longitudinal restraint. The results from these reports were used to generate a list of initial parameters included in the UMN field and analytical studies, and to provide a comparison to the field observations and parametric study results. Table 1 shows a summary of the dominant parameters found to affect transverse cracking, including the findings of the five aforementioned references and the UMN results. 


\section{FIELD INVESTIGATION}

The UMN field survey included 72 bridges ( 34 composite simply-supported prestressed girder bridges, 34 composite continuous steel plate girder bridges, and 4 composite continuous steel rolled wide flange girder bridges). All of the bridges were located in and around the Minneapolis/St. Paul metropolitan region. The bridges were selected for the study to include a wide range of roadway types (local or interstate), ages (30 years old to recently constructed), lengths, and overall condition ratings.

Crack patterns were documented and the bridges were given a UMN bridge deck condition rating based on the extent of transverse crack damage. The condition rating scale adopted by UMN was similar to that used by the Minnesota Department of Transportation (Mn/DOT) for overall condition rating: the ratings ranged from ' 5 ' to ' 9 ' with ' 9 ' describing an undamaged condition. Crack width measurements and crack spacings recorded with detailed top crack pattern documentation were used in the UMN evaluation. The extent of longitudinal cracks, "map" cracks, and transverse cracks located in the negative moment region were not considered in assigning the rating. The basic criteria used to rate each span of each bridge were as follows:

' 9 ' - No cracks.

' 8 ' - A few single cracks $<0.75 \mathrm{~mm}(0.03$ ') wide.

' 7 ' - Single cracks with a crack width $<0.75 \mathrm{~mm}(0.03$ ') and crack spacing greater than approximately $1.82 \mathrm{~m}\left(6^{\prime}\right)$.

' 6 ' - Areas with high crack density. Crack width $<0.75 \mathrm{~mm}(0.03$ ') and crack spacing between approximately $0.91 \mathrm{~m}\left(3^{\prime}\right)$ and $1.82 \mathrm{~m}\left(6^{\prime}\right)$ [or single transverse cracks with a crack width $\left.>0.75 \mathrm{~mm}\left(0.03^{\prime \prime}\right)\right]$.

' 5 ' - Areas with high crack density and large crack width. Crack width $>0.75 \mathrm{~mm}(0.03$ ') and crack spacing closer than approximately $0.91 \mathrm{~m}\left(3^{\prime}\right)$.

In addition to recording crack patterns on the top side of the bridge deck, bottom crack patterns were documented, where possible, to locate the cracks with respect to bridge elements such as fascia girders, joints in concrete parapets, cross frames, and field splices. Field observation logs were also written for each bridge to document individual bridge cracking characteristics. The detailed documentation of bridge deck cracking for numerous bridges was an essential tool in identifying the possible crack sources. 
Design, material, and construction related data were collected for each bridge and documented in a database for the parameters considered to be relevant to bridge deck cracking (Table 1) [see Eppers et al. (5) for a detailed account of material collected per bridge]. General information for each of the bridges included: year of construction, overlay placement and redecking (when applicable); detailed bridge and deck dimensions; average daily traffic; inventory and operating rating; Mn/DOT condition rating; and UMN deck condition rating (per span). Design information, documented separately per bridge and per span, was available for 55 bridges, and included: span lengths, girder spacings, deck reinforcement and composite stud details. In addition, "flexibility" parameters such as the beta $(\beta)$ ratio (defined later) and EI/L were calculated for the steel bridges in the study. Material information, documented separately for deck and overlay concrete, was available for 21 bridges, and included: cement supplier and detailed mix design data. Construction information, available for 18 bridges, included: deck contractor, joint type, date when the deck was placed, and highest and lowest air temperatures on the day of the deck pour.

Due to the limited construction information available for the bridges, the UMN field study was not able to include comprehensively many construction related parameters currently considered to be relevant to deck cracking, including: time of placement, curing period, curing methods, pour length and sequence, finishing procedures, vibration techniques, relative humidity, and wind velocity.

Typical documentation, presented per bridge in Eppers et al. (5), includes a table detailing the primary features of the bridge, a top and bottom crack pattern, and several photographs highlighting the cracking. A sample of this information is given in Table 2 and Figures 1-4 for Bridge No. 19882 [see Eppers et al. (5) for a description of each field in the table]. This steel girder bridge, built in 1985, was the newest bridge in the worst condition. It had many factors contributing to its large amount of cracking in both the negative and positive bending moment regions (5). 
To evaluate the influence of each parameter on transverse cracking, the design, material and construction-related parameters were compared to the UMN deck condition rating on twodimensional graphs (5). Linear regression was used to determine the correlation with deck cracking tendency. Examples of these graphs are given in Figures 5 to 7 and are discussed in the following sections.

\section{Design-Related Parameters}

Overall, simply-supported prestressed girder bridges were found to be in good condition relative to continuous steel girder bridges. This was attributed to reduced end restraint and beneficial creep and shrinkage characteristics of the prestressed bridge girders $(5,6)$. Evidence showed that restrained concrete deck shrinkage in composite continuous steel bridges caused substantial cracking in both old and new bridges.

One of the dominant design parameters identified in the references as affecting transverse cracking was a restraint coefficient, $\beta$ (7). The $\beta$ quantity indicates the degree of deck restraint that is provided by the steel girders and is calculated as the ratio of the cross-sectional area of the steel girder to the effective area of the concrete slab assuming girder center-to-center distance for the cross section. Ducret et al. (7) provides guidance on the ranges of $\beta$ values and their implications (e.g., $\beta \leq 0.05$ indicates limited restraint from the girders and lower probability of premature deck cracking; $\beta>0.12$ indicates substantial restraint from the girders and higher probability of premature deck cracking).

Figure 5 shows the $\beta$ parameter plotted versus the UMN condition rating for the steel bridges in the study (5). The data points represent individual spans and their respective condition ratings identified according to whether they were exterior or interior spans of a multispan bridge (i.e., 'end spans-multi' or 'contin. spans-multi') or part of a two-span bridge (i.e., end span-2 span). The correlation coefficients, $R^{2}$ values, obtained from the linear regression analyses and corresponding best-fit lines are also shown in the figures. A perfect correlation would give $R^{2}=1$; 
the low correlation coefficients were not unexpected due to the interaction of multiple variables combining to affect the transverse cracking in each bridge.

The $\beta$ values given in Figure 5 were calculated just past the splice, towards the positive moment region of each span. Most of the $\beta$ values fell within the "limited risk" range, between 0.05 and 0.08 , with the trend in the predicted direction (i.e., decreasing crack tendency with decreasing $\beta$ ). Several "outliers" in the data are shown encircled with the specific Mn/DOT bridge number identified adjacent to the data point. These data may be associated with explanations for their performance. For example, the high condition rating for Span 3 of Bridge No. 62813 was attributed to the beneficial effect of the expansion joint in the bridge deck at midspan on Span 3.

Another design parameter thought to affect transverse cracking was the transverse top reinforcement bar size and spacing. Figure 6 shows a plot of the bar spacing versus UMN condition rating for the steel girder bridges. The data are separated according to bar size and corresponding bridge span type. The graph indicates a trend for improved UMN condition rating with increased bar spacing. The steel bridges that performed best had either No. 5 bars $(16 \mathrm{~mm}$ or $5 / 8$ " diameter) at $140 \mathrm{~mm}$ (5.5") spacing or No. 6 bars (19 mm or $6 / 8$ " diameter) at $165 \mathrm{~mm}$ or $178 \mathrm{~mm}$ (6.5" or 7") spacing. Of these categories, the No. 5 bars performed better than the No. 6 bars. Note that bar size was not a significant factor for the deck condition ratings of the prestressed girder bridges.

Some of the highest correlations were found with respect to inventory and operating ratings versus UMN condition rating. Data indicated that multiple span steel bridges designed for an increased maximum sustained vehicle load resulted in reduced cracking tendency.

Additional dominant design parameters associated with increased transverse cracking tendency included: interior spans of continuous multi-span bridges constructed with girders having increased stiffness [this correlated well with the results of the computational study (6)]; and bridges with thin decks [i.e., $159 \mathrm{~mm}\left(6^{1 / 4}\right)$ ], i.e., older bridges. Cracks occurred frequently at locations of railing parapet joints, particularly in the negative moment region. Cracks were also 
observed to develop at cross frame locations. Less cracking occurred in bridges with expansion joints compared to similar bridges without expansion joints. Eppers et al. (5) provides further documentation of these parameters.

\section{Materials-Related Parameters}

Restraint of concrete deck shrinkage was believed to be the primary cause of transverse cracks. Materials-related parameters believed to affect concrete shrinkage properties include batch proportioning and material properties of the individual concrete components (cement, aggregate, and water). Shrinkage is also affected by construction-related parameters (e.g., curing procedures) discussed in the next section.

In this study, the dominant material parameters found to be associated with transverse cracking in bridge decks were cement content, aggregate type and quantity, and air content. These results are described below, based on data obtained from materials reports for 21 of the bridge deck mixes (12 prestressed and 9 steel girder bridges).

Cement contents were compared with results obtained from other researchers. Krauss et al. (4) considered cement content to be a major factor contributing to premature bridge deck cracking. In concrete restraint tests, they observed the concrete mix with the highest cement content, 4920 $\mathrm{N} / \mathrm{m}^{3}\left(846 \mathrm{lb} / \mathrm{yd}^{3}\right)$, cracked first, while the mix with the lowest cement content, $2730 \mathrm{~N} / \mathrm{m}^{3}$ (470 $\left.\mathrm{lb} / \mathrm{yd}^{3}\right)$, cracked last. For mixes with typical to moderately high cement contents, cracking was not dramatically affected by water content or water-cement ratio within the range tested $(0.35$ 0.50 ).

Table 3 summarizes the UMN water and cement content data for the prestressed and steel girder bridges. The cement contents, which ranged from 3590 to $4030 \mathrm{~N} / \mathrm{m}^{3}$ ( 617 to $693 \mathrm{lb} / \mathrm{yd}^{3}$ ), have been subdivided into low, moderate, and high cement content categories for the two types of bridges. A general trend of increased cracking with increased cement content can be discerned. The lower cement content mixes typically had higher water-cement ratios and typically performed well, with the exception of Bridge No. 27856 [the low condition rating was attributed 
to an early April deck pour with high/low temperatures of $\left.8.9^{\circ} \mathrm{C} / 3.3^{\circ} \mathrm{C}\left(48^{\circ} \mathrm{F} / 38^{\circ} \mathrm{F}\right)\right]$. This data indicated that high water content and water-cement ratios alone are not good indicators of potential for concrete shrinkage. Reduced paste volume and reduced cement-to-void ratios corresponded with reduced cracking tendencies (5).

The low cement concretes with reduced paste volume are associated with reduced heat of hydration. Krauss et al. (4) and results of the parametric study (6) suggested that the initial thermal stresses (related to heat of hydration) are more important than later thermal stresses (i.e., subsequent weather-related temperature gradients).

Comparison of 21 bridges on the basis of aggregate type and quantity showed that increased aggregate quantity may result in reduced cracking (5). For example, the steel bridge that exhibited the least amount of cracking contained the highest quantity of aggregate $\left[10,720 \mathrm{~N} / \mathrm{m}^{3}\right.$ $\left(1845 \mathrm{lb} / \mathrm{yd}^{3}\right)$ of coarse aggregate and $6,994 \mathrm{~N} / \mathrm{m}^{3}\left(1,203 \mathrm{lb} / \mathrm{yd}^{3}\right)$ of fine aggregate], and a relatively low cement content $\left[3,820 \mathrm{~N} / \mathrm{m}^{3}\left(657 \mathrm{lb} / \mathrm{yd}^{3}\right)\right]$. Increasing the unit volume of aggregate, correspondingly reduces the paste volume, which results in a concrete with reduced shrinkage and therefore reduced cracking. Krauss et al. (4) suggested that aggregates with high modulus of elasticity, low shrinkage, low coefficient of thermal expansion, and high conductivity result in reduced shrinkage. However, aggregates with higher modulus of elasticity increase the modulus of elasticity of the concrete, often resulting in greater shrinkage restraint; thus, partially offsetting the beneficial effects of reduced shrinkage.

The ranges of air contents included in the materials reports of the 21 bridges ranged from $5 \%$ to $6 \%$. With this limited data, the trend correlated with the results of other studies (2), which indicated reduced cracking with increased air content $(>5.5 \%)$.

\section{Construction-Related Parameters}

High and low temperatures on the day of concrete deck placement were documented for 18 bridges ( 10 prestressed and 8 steel girder bridges). Figure 7 shows the results for the prestressed girder bridges. Both the prestressed and steel girder bridges showed a slight trend in which 
higher air temperature on the day of deck placement resulted in reduced cracking. Three of the four lowest condition prestressed bridges had low air temperatures recorded at or below $1.7^{\circ} \mathrm{C}$ $\left(35^{\circ} \mathrm{F}\right)$; the other low condition prestressed bridge had an exceptionally high air temperature at deck placement, near $32^{\circ} \mathrm{C}\left(90^{\circ} \mathrm{F}\right)$. Note, however, that two prestressed bridges, Bridge Nos. 13811 and 27790 , were cast during extremely low and high temperatures, respectively, yet had high condition ratings.

From graphs of the temperature data, it was determined that the bridges that exhibited less cracking were cast on days when the air temperature was between a high of 18 to $21^{\circ} \mathrm{C}$ (65 to $70^{\circ} \mathrm{F}$ ) and a low of 7 to $10^{\circ} \mathrm{C}\left(45\right.$ to $\left.50^{\circ} \mathrm{F}\right)$. There was some evidence (from five deck placements) that if the ambient air temperature does not exceed either $29^{\circ} \mathrm{C}\left(85^{\circ} \mathrm{F}\right)$ or $4^{\circ} \mathrm{C}\left(40^{\circ} \mathrm{F}\right)$ (i.e., exceptionally high or low) that a large temperature range on the day of a deck placement may result in increased cracking (5). In warm weather, Krauss et al. (4) suggested that night pours may reduce initial thermal shrinkage by decreasing the concrete peak hydration temperature due to effects of the lower ambient air temperature.

It was not possible to determine whether effects of thermal gradients over the life of the bridge had a greater impact on the transverse cracking phenomena in comparison with the temperature conditions during casting and initial curing. There were no records indicating when the cracks first appeared relative to deck casting. However many new bridges (as well as old bridges) were observed to exhibit deck cracking.

Staged deck construction also appeared to have an effect on deck cracking. Some bridges, which had transverse bar lap splices (indicating staged construction), developed transverse cracks along one half of the longitudinal direction of the bridge indicating that deck shrinkage may have been restrained on the half of the bridge that was poured later (5).

As mentioned earlier, the UMN study was not able to include many construction-related parameters relevant to deck cracking due to the limited bridge records. Additional construction related parameters considered to be important include: curing period, curing methods, pour 
length and sequence, finishing procedures, vibration techniques, and weather conditions (e.g., relative humidity and wind velocity).

\section{Summary of Field Study}

Of the 34 prestressed bridges surveyed, 25 rated a condition ' 8 ' or better. There were two factors, in addition to temperature on the day of the deck pour, that appeared to contribute to transverse cracking: deck overlays and deck reconstructions. In the case of Bridge No. 9081 with a condition rating of '7.5,' the deck was reconstructed on a 29 -year-old bridge. At this age, the creep and shrinkage in the prestressed concrete girders had already stabilized such that the girders would restrain the shrinkage of the deck concrete similarly to the restraint provided by steel girder bridges.

For the steel girder bridges, only 12 of the 38 bridges rated a condition ' 8 ' or better. In general, interior spans on multiple span bridges (e.g., Figures 1-4) and curved portions of bridges (particularly inside portions of the curves) were in poorest condition, most likely due to higher restraint provided by these conditions $(5,6)$. Bridge decks poured during unfavorable temperature conditions or with unfavorable mix proportions exhibited increased cracking (5).

In actual bridges, multiple combinations of factors exist and it is difficult to pinpoint the exact reason for the degree of cracking in the deck. Therefore, each of the bridges was examined as a whole to decipher the reasons for the observed cracking. These findings are reported in detail in Eppers et al. (5). As an example, Bridge No. 27703 had a stud configuration of 4 rows of $22 \mathrm{~mm}$ $\varnothing \times 152 \mathrm{~mm}$ high (7/8" $\varnothing \times 6$ ") studs, which may have contributed to the deck restraint. This stud configuration represented the greatest number of rows, largest diameter and tallest studs included in the study. Transverse cracks extended across the entire deck, with widths averaging $0.5 \mathrm{~mm}$ (0.02"). Similar cracks were observed in other bridges (Bridge Nos. 62889, 62888, 62894,62817 ) with similar stud configurations. In addition, the staggered cross frames in the

bridge seemed to cause local crack concentrations that were spaced more closely than might be expected in the case of non-staggered cross frames, which are spaced at larger distances (6). 
Relating the field notes, crack documentation, and available design-, material- and constructionrelated information, for each particular bridge provided better insight into the combined effects of particular variables and the reasons for the anomalies observed within the parameter versus condition rating graphs discussed above.

\section{SHRINKAGE STUDY}

One of the suspected reasons for increased transverse cracking observed in bridge decks was a change in the standard concrete mix design used in the State of Minnesota from what is termed a " $3 \mathrm{Y}$ " mix to a " $3 \mathrm{X}$ " mix. To reduce the occurrence of transverse cracking, Mn/DOT standard deck mix specifications returned to the $3 \mathrm{Y}$ mix in recent years. A $3 \mathrm{X}$ mix differs from a $3 \mathrm{Y}$ mix largely in the cement content: for typical deck concrete, $3 \mathrm{X}$ mixes have a cement content of approximately $4068 \mathrm{~N} / \mathrm{m}^{3}\left(700 \mathrm{lb} / \mathrm{yd}^{3}\right)$ vs. a cement content of approximately $3719 \mathrm{~N} / \mathrm{m}^{3}(640$ $\mathrm{lb} / \mathrm{yd}^{3}$ ) for $3 \mathrm{Y}$ mixes. The UMN study included characterization of the shrinkage characteristics of both types of mixes (6). Five batches containing multiple samples of the two concrete deck mixes were cast in the field during corresponding deck pours and subsequently monitored in the laboratory to determine the concrete shrinkage characteristics with respect to time. A slightly modified version of the ASTM C157-93 test method was used for monitoring the free shrinkage of the concrete specimens. The relative humidity was $60 \%$ for this study, rather than $50 \%$ as suggested in ASTM C157-93, and the specimens were not placed in saturated lime water upon their removal from the forms, so as to better simulate field conditions.

Figure 8 shows a plot of shrinkage versus time data obtained for the $3 \mathrm{X}$ and $3 \mathrm{Y}$ mixes. Because the results indicated that there was not a significant difference in the free shrinkage observed for the $3 \mathrm{X}$ and $3 \mathrm{Y}$ mixes, upper and lower bound shrinkage curves (not shown) were generated by combining the results of shrinkage tests from both mixes. Figure 8 also shows the nominal ACI 209 shrinkage curve (8). While the free shrinkage of the $3 \mathrm{X}$ and $3 \mathrm{Y}$ mixes was comparable to that of the ACI 209 shrinkage curve, both types of mixes were observed to exhibit substantially higher initial shrinkage rates relative to that predicted by ACI 209 (8). This may be attributed to the different curing procedures employed by the ASTM standard versus those 
experienced in the field. The effects of rate of shrinkage and amount of free shrinkage were investigated in the parametric study, discussed in the next section, by including the upper and lower bound shrinkage curves along with the ACI 209 shrinkage curve in the analyses. The preponderance of cracks in both old and (especially) new bridges suggested that early bridge deck cracking was exasperated by the higher initial shrinkage rates (6), coupled with the additional parameters highlighted in the field and parametric studies.

\section{PARAMETRIC STUDY}

The inability to isolate individual parameters affecting transverse cracking of bridge decks in the field study was a chief cause of the generally poor correlation coefficients associated with the 2$D$ graphs (e.g. Figs. 5-7). To isolate the effects of individual parameters on transverse bridge deck cracking, a computational parametric study was conducted (6) using the program PBEAM (9). This finite element software used a fiber or layered analysis approach, in which the cross section (girder and slab) were discretized into layers through the thickness. Displacement and rotational degrees-of-freedom were modeled in 2D at the centroidal axis of the element. Uniaxial nonlinear stress-strain properties were identified and tracked independently for each layer.

Stress-resultants (forces and bending moments) were computed by numerical integration through the cross section. Twenty to thirty elements were typically used along the length of each girder. The program enabled time-dependent analyses of single-span steel or concrete girders made composite with the casting of a concrete deck. Nonlinear concrete constitutive properties were modeled, including cracking in tension. In addition, creep, shrinkage, and aging of the concrete deck and prestressed girders, and relaxation of the prestressing strands, were modeled. With respect to steel, all stresses were such that the steel remained in the linear elastic range. To represent the boundary conditions of continuous steel girder bridges, supports were modeled as either fixed (representing continuous spans), pinned, or roller. Le et al. (6) reported the details of the modeling assumptions, the results of the specific analyses conducted, and the successful, general correlation of the nonlinear analysis results with the crack patterns obtained on three bridges investigated in the field study. A summary of key results from the study follows. 
The parametric study was conducted using prototype girders, with base cases modeled from two bridges chosen from among the inventory of 72 bridges investigated in the field study. One was a prestressed concrete bridge (Bridge No. 19042), and the other was a two-span continuous steel girder bridge (Bridge No. 62888). Starting with these base cases, a large number of nonlinear static analyses were conducted, varying key parameters. The variables considered for the prestressed girder bridge parametric study included: the timeline (relative times for strand tensioning, casting, strand release, and deck casting); and shrinkage properties (ACI 209 (8) shrinkage curve versus upper and lower bound shrinkage curves obtained from the shrinkage study). The base case parameters and variations included in the parametric study of the steel bridges are given in Table 4 .

For the case of the prestressed girder bridges investigated with typical construction timelines, none of the prestressed girder bridges indicated the development of transverse cracking during the course of the bridge life studied (10,000 days). This was due largely to the lack of restraint offered by the simply-supported end conditions, and the fact that the concrete girders tended to shrink over time, although not necessarily at the same rate as the deck. The highest tensile stresses in the deck resulted from a timeline that modeled delayed strand release (e.g., 66 hours after casting, as may occur over a weekend). When the concrete was older at release, there was less elastic shortening due to the larger concrete modulus (therefore, there was less loss of prestress), and the aged girder caused a higher differential shrinkage between the girder and the deck. Similar behavior was evident in the investigation of a potential redecking situation, in which case the deck was cast on a 20-year-old girder. In this case, the deck cracked due to the restraint caused by the differential shrinkage between the preshrunk girder and the freshly cast deck.

The following is a summary of the steel girder bridge results (the crack pattern for Bridge No. 62888 is shown in Figure 9):

Effect of shrinkage - Differential shrinkage between the concrete deck and girder was the main cause of deck cracking. This was particularly evident in the case of the steel girder bridges and 
the redecked prestressed girder bridges. The effects of two shrinkage parameters were investigated: the initial shrinkage rate and ultimate shrinkage. Analyses showed that the ultimate shrinkage did not have a significant effect on the tensile stresses in the deck because creep mitigates these stresses. The rate of shrinkage, however, had a large impact on the extent of deck cracking.

The Mn/DOT 3X and 3Y mixes, studied in this project, exhibited high initial rates of shrinkage in comparison with the ACI 209 curve. Analyses showed that using these mixes in bridge decks resulted not only in more cracking, but also in very early cracking in the deck lifetime. Reductions in the initial rate of shrinkage clearly reduced early transverse deck cracking.

Effect of end conditions - The end conditions had a great effect on the extent of transverse cracking. As expected, the most extensive transverse cracking was associated with the most restrained case (i.e., fixed-fixed). In the fixed-fixed case (simulating an interior span), cracks developed near the support in the negative moment region. For both medium and large girder stiffnesses $\left(\mathrm{I}_{\text {girder }}\right)$, the deck stresses (and cracking) were more uniformly distributed than for the case of more flexible girders. For girders with low stiffness, the tensile stresses increased at midspan (in the positive moment region). This resulted because the girder deflected upward (from its downward dead load deflected position) at midspan due to bending induced from restrained shrinkage. This caused further tension in the deck at midspan and compression at the ends. Cross frames and splices had little effect on the stresses in the deck in the stiffer girder cases, whereas, there was a significant change in deck stresses associated with cross frames and splices for the more flexible girders. In the latter case, the stiffness attributed to the cross frames and diaphragms was more noticeable.

The fixed-roller end condition (simulating one span of a two-span bridge) enabled movement of the girder to relieve tensile stresses due to deck shrinkage in the positive moment region. Again, cracks were likely to occur near the fixed end (in the negative moment region) when large girders were used. The cross frames stiffened the girder and provided more uniform restraint, causing 
cracks to extend into the positive moment region. The splices stiffened the girder near the fixed end, resulting in cracks concentrating near the splice.

Cracks for the pinned-roller (simply-supported) cases were never observed during the analyses performed.

Whereas the end conditions had the greatest effect on the extent of cracking, the girder stiffnesses, cross frames, and splices, dictated the crack locations.

Effect of girder stiffness $\left(\mathbf{I}_{\text {girder }}\right)$ - The stiffer girders bent little as the deck shrunk. As a consequence more uniform stresses developed throughout the deck, which often caused uniform cracking. Flexible girders bent upward due to shrinkage, which increased the tensile stresses at midspan, reducing the tensile stresses at the ends.

Effect of cross frames - Cross frames resisted some of the vertical deflection of the flexible systems, causing the cracks to extend into the positive moment region. When the cross frames were staggered, they provided more uniform distribution of stiffness to resist vertical deflection, which further promoted the extension of cracks into the positive moment region.

Effect of splices - Splices had little effect on transverse cracking when the girders were stiff and the end restraints were fixed. For the fixed-roller case, cracks concentrated in the splice region. This was attributed to the concentrated stresses at the discontinuity caused by the change in moment of inertia at the splice locations.

Effect of deck modulus $\left(\mathbf{E}_{\boldsymbol{c}}\right)$ - Lowering the deck modulus reduced the concrete tensile stresses. The lower $\mathrm{E}_{\mathrm{c}}$ enabled the girder to undergo larger shrinkage deformations before cracking. It should be noted, however, that a reduction in $\mathrm{E}_{\mathrm{c}}$ may also be associated with a reduced concrete cracking stress (or tensile capacity). 
Effect of temperature differentials - Differential temperatures between the deck concrete and steel girder were introduced at the time of deck casting to simulate the effects due to concrete heat of hydration. Four scenarios were investigated (see Table 0), including cases that considered the effect of initially preheating the girder. Because the girder was modeled as initially level (zero deflection), the addition of dead load caused a downward deflection in the model. Consequently, as the temperature increased, the girder underwent increased downward deflections. Upon cooling, the girder contracted and underwent an upward deflection that resulted in reduced compressive stresses in the top of the deck. Further studies should be conducted to determine the potential beneficial effects of girder preheating in the case of cambered conditions. In this case, the opposite trends would be expected.

\section{Comparison with Field Study}

The results of the parametric study correlated well, in a general sense, with the field study. To verify the results of the analytical parametric study more specifically, the prototype bridge results were compared with the observed behavior in the field. In the case of the prestressed girder bridge (Bridge No. 19042), there was good agreement between the analyses and the bridge performance--no cracks were observed in the real bridge. Good agreement was also observed in the case of the two-span steel girder bridge (Bridge No. 62888). Cracks were observed to develop near the roller, and increased crack concentrations occurred near the fixed end. The only discrepancy between the analyses and field observations was that cracks were also found near midspan in the analysis, which was not the case in the field (see Figure 9). A third bridge was also investigated (Bridge No. 19882) to compare the results of the analyses with a continuous steel girder bridge of three or more spans (the crack pattern for this bridge is shown in Figure 4). In both the analyses and field observations, the interior span cracked uniformly throughout and the end span developed two primary cracks. 


\section{CONCLUSIONS}

Overall, concrete decks on simply-supported prestressed girder bridges were found to be in good condition relative to the decks on continuous steel girder bridges. The deck concrete never cracked in the parametric study and rarely cracked in the field study in the case of the prestressed concrete girder bridges. This was attributed to reduced end restraint and beneficial creep and shrinkage characteristics of the prestressed girders. The few prestressed girder bridges that consistently performed poorly were observed to be either bridges with reconstructed or reoverlayed decks or bridges which had deck pours during extreme temperatures. Cracking due to deck reconstruction was attributed to the restrained shrinkage of the newly poured concrete decks or overlays caused by the restrained shrinkage provided by the aged (preshrunk) prestressed bridge girders.

For concrete decks on steel girder bridges, end restraint and shrinkage were the most important factors contributing to extensive deck cracking. Increased transverse cracking of bridge decks on steel girder bridges was associated with interior spans (especially with stiff girders) compared to end spans, curved bridges, No. 6 top transverse bars compared to No. 5 bars [No. 5 bars at 125 to $140 \mathrm{~mm}$ (5 to $51 / 2$ ") spacing performed the best], and increased restraint due to stud configuration, girder depth or close girder spacing. Cross frames were observed to cause stress concentrations that often led to cracks located near diaphragms. Staggered cross frames were observed to initiate more closely spaced cracks than non-staggered cross frames because the distance between cross frame attachments along the girders was typically shorter for staggered cross frames. Staged construction was suspected to contribute to increased deck cracking. Expansion joints in steel girder bridge decks were observed to reduce crack occurrence.

Dominant material-related parameters associated with transverse cracking included: cement content, aggregate type and quantity, air content, rate of shrinkage, and deck concrete modulus of elasticity. Ambient air temperature at deck placement was the only dominant constructionrelated information found available in the field study (5) although other factors may be important including curing period, curing methods, pour length and sequence, finishing procedures, vibration techniques, and weather conditions (e.g., relative humidity and wind velocity). The 
parametric study also noted the effect of temperature differentials between the deck concrete and the girder due to hydration effects.

\section{RECOMMENDATIONS}

Based on the results from this research and that reviewed by the investigators, the following recommendations were made.

- Reduce deck shrinkage:

- Use maximum cement contents of approximately $3,779 \mathrm{~N} / \mathrm{m}^{3}$ to $3,837 \mathrm{~N} / \mathrm{m}^{3}\left(650 \mathrm{lb} / \mathrm{yd}^{3}\right.$ to $660 \mathrm{lb} / \mathrm{yd}^{3}$ ) -- this reduces the paste volume and the peak heat of hydration temperature.

- Use low water-cement ratios.

- Use minimum air contents of approximately $5.5 \%$ to $6.0 \%$.

- Maximize coarse aggregate content [mixes that performed well contained approximately $10,460 \mathrm{~N} / \mathrm{m}^{3}$ to $10,750 \mathrm{~N} / \mathrm{m}^{3}\left(1800 \mathrm{lb} / \mathrm{yd}^{3}\right.$ to $\left.1850 \mathrm{lb} / \mathrm{yd}^{3}\right)$.

- Maximize fine aggregate content [mixes that performed well contained approximately $\left.6,976 \mathrm{~N} / \mathrm{m}^{3}\left(1200 \mathrm{lb} / \mathrm{yd}^{3}\right)\right]$.

- Improve curing practices in the field.

- Limit ambient air temperatures during casting and reduce heat of hydration:

- Place concrete decks only when the low ambient air temperature is above approximately 4 to $7^{\circ} \mathrm{C}\left(40\right.$ to $\left.45^{\circ} \mathrm{F}\right)$

- Place concrete decks only when the ambient air temperature is below approximately 29 to $32^{\circ} \mathrm{C}\left(85\right.$ to $\left.90^{\circ} \mathrm{F}\right)$

- Avoid pouring concrete on days when there is a large temperature range [greater than approximately $\left.10^{\circ} \mathrm{C}\left(50^{\circ} \mathrm{F}\right)\right]$ 
- Best results were seen when the ambient air temperature ranged between highs of approximately 18 to $21^{\circ} \mathrm{C}\left(65\right.$ to $\left.70^{\circ} \mathrm{F}\right)$ and lows of approximately 7 to $10^{\circ} \mathrm{C}(45$ to $\left.50^{\circ} \mathrm{F}\right)$

- Other studies (2-4) recommended the use of Type II (low heat) cement and placement of deck concrete. in the evening (during warmer months) to reduce peak hydration temperatures.

- Preheating the steel girder to reduce the temperature differential upon concrete hydration may have potential merit and should be investigated further. Cold weather pours (for steel girder bridges) were observed to consistently result in extreme cracking in the field study (5).

- Reduce longitudinal restraint of the concrete deck:

- Bridge decks on simply supported prestressed girders showed significantly less cracking than decks on continuous steel girders in the UMN field study.

- Deck continuity may be reduced by using bridge deck expansion joints (or using simply supported spans).

- Girder restraint (represented by $\beta$ ) can be reduced by increasing girder spacing.

- Shear connector configuration with fewer number of rows, smaller diameter and shorter studs to reduce overall stud restraint.

- Avoid thin decks:

- Thinner decks $\left[159 \mathrm{~mm}\left(6^{1 / 4}\right.\right.$ ")] were observed to result in increased cracking in the field study.

- Limit transverse reinforcement bar size and/or maximize transverse bar spacing

- Recommend using No. 5 bars at $140 \mathrm{~mm}$ (5.5") spacing or No. 6 bars at 165 or $178 \mathrm{~mm}$ (6.5 or 7") spacing.

These recommendations are made specifically to reduce the occurrence of transverse cracking in bridge decks. Note that some of these modifications may significantly affect bridge 
performance. For example, use of simply-supported steel girders typically results in deeper sections or larger deflections. In implementing these recommendations the engineer should evaluate the possible effects on the other aspects of bridge performance. 


\section{REFERENCES}

1. Kochanski, T., Parry, J., Pruess, D., Schuchardt, L. and Ziehr, J., "Premature Cracking of Bridge Decks Study.” Wisconsin Department of Transportation, October 1990.

2. Schmitt, T. R. and Darwin, D., "Cracking in Concrete Bridge Decks." Report No. KTRAN:KU-94-1, Kansas Department of Transportation, April 1995.

3. Babaei, K. and Purvis, R. L., "Prevention of Cracks in Concrete Bridge Decks." Report on Laboratory Investigations of Concrete Shrinkage, Wilbur Smith Associates, Research Project No. 89-01 for the Pennsylvania Department of Transportation, November 1995.

4. Krauss, P. D. and Rogalla, E. A., "Transverse Cracking in Newly Constructed Bridge Decks." NCHRP Report No. 380, Transportation Research Board, Washington D. C., 1996.

5. Eppers, L., French, C., and Hajjar, J. F., "Transverse Cracking in Bridge Decks: Parametric Study," Mn/DOT Final Report, 1998.

6. Le, Q. T. C., French, C., and Hajjar, J. F., "Transverse Cracking in Bridge Decks: Parametric Study,"Mn/DOT Final Report, 1998.

7. Ducret, J., Lebet, J. and Monney, C., "Hydration Effects and Deck Cracking During the Construction of Steel Concrete Composite Bridges." ICOM-Construction Metallique, Article ICOM 359, July 1997.

8. American Concrete Institute Committee 209, Subcommittee II, "Prediction of creep, shrinkage and temperature effects," Detroit, October 1978.

9. Suttikan, Chaichan, "A Generalized Solution for Time-Dependent Response and Strength of Noncomposite and Composite Prestressed Concrete Beams," Ph.D. Dissertation, The University of Texas at Austin, January 1978. 

Table 1 Summary of dominant parameters affecting transverse cracking in concrete bridge decks

\begin{tabular}{|c|c|c|c|c|c|c|}
\hline Design & Major & Moderate & Minor & $\begin{array}{c}\text { No } \\
\text { effect }\end{array}$ & $\begin{array}{l}\text { Incon- } \\
\text { clusive }\end{array}$ & $\begin{array}{c}\text { No } \\
\text { analysis }\end{array}$ \\
\hline $\begin{array}{l}\text { Restraint - } \\
\text { Girder End Support Condition and Girder Type - } \\
\text { - Spans with fixed-ended girders have increased } \\
\text { cracking over those with pin-ended girders } \\
\text { Steel girder bridges have more cracking than } \\
\text { prestressed girder bridges }\end{array}$ & $\begin{array}{r}\mathbf{K} \\
\mathbf{M}\end{array}$ & $N$ & & & & $\begin{array}{l}\text { PIW } \\
\text { KPIW }\end{array}$ \\
\hline $\begin{array}{l}\text { Restraint - } \\
\text { Girder Size, Girder Spacing, and Span Length - } \\
\text { - Deep girders at a close spacing have increased } \\
\text { cracking tendency } \\
\text { Longer span lengths have increased cracking } \\
\text { tendency }\end{array}$ & $\begin{array}{l}\mathrm{N} \text { I } \mathrm{M} \\
\mathrm{W}\end{array}$ & & $\mathbf{M}$ & $\mathrm{K}$ & & $\begin{array}{l}\mathrm{KP} \mathrm{W} \\
\mathrm{PI}\end{array}$ \\
\hline $\begin{array}{l}\text { Deck Thickness - } \\
\text { - Cracking increases with a decrease in deck } \\
\text { thickness }\end{array}$ & W & $\mathrm{N} \quad \mathrm{M}$ & & & $\mathbf{K}$ & PI \\
\hline $\begin{array}{l}\text { Transverse Top Deck Reinforcement } \\
\text { - } \quad \text { Larger bar size increases cracking tendency } \\
\text { - } \quad \text { increased bar spacing increases cracking tendency } \\
\text { - } \quad \text { Area of bar/bar spacing }\end{array}$ & K W M & $\begin{array}{lr}\text { K } & \mathbf{M} \\
\mathbf{K} & \mathbf{W M}\end{array}$ & $\mathbf{N}$ & & & $\begin{array}{l}\text { N PI } \\
\text { N PIW } \\
\quad \text { PI }\end{array}$ \\
\hline $\begin{array}{l}\text { Longitudinal Top Quantity of Steel - } \\
\text { Reduced quantity of steel increases cracking }\end{array}$ & & $\mathrm{W}$ & & $\mathbf{M}$ & & NKPI \\
\hline Parapet Detailing & W & $\mathbf{M}$ & & & & NKPI \\
\hline \multicolumn{7}{|l|}{ Material } \\
\hline $\begin{array}{l}\text { Cement Content, Water Content, and w/c Ratio - } \\
\text { increased cement content increases cracking } \\
\text { tendency } \\
\text { - } \quad \text { increased water content increases cracking } \\
\text { tendency } \\
\text { - higher w/c ratio increases cracking tendency }\end{array}$ & $\begin{array}{l}\text { NKIWM } \\
\text { P }\end{array}$ & $\begin{array}{rr} & \\
\text { NK } & M \\
\text { NKP } & M\end{array}$ & & & W & $\begin{array}{l}\text { IW } \\
\text { I }\end{array}$ \\
\hline $\begin{array}{l}\text { Aggregate Type and Aggregate Quantity - } \\
\text { - low aggregate stiffness increases shrinkage } \\
\text { - low aggregate volume increases shrinkage }\end{array}$ & $\begin{array}{l}\text { NP } \\
N \quad \text { W }\end{array}$ & $\mathbf{M}$ & & & & $\begin{array}{l}\mathrm{K} \text { IWM } \\
\mathrm{K} \text { PI }\end{array}$ \\
\hline $\begin{array}{l}\text { Air Content - } \\
\text { - low air content increases cracking tendency }\end{array}$ & K & $\mathbf{M}$ & & & & N PIW \\
\hline Cement Type & NPI W & & & & & $\begin{array}{ll}\mathrm{K} & \mathrm{M} \\
\end{array}$ \\
\hline Compressive Strength & & & $\mathrm{NK} \mathrm{M}$ & & & $\overline{\text { PIW }}$ \\
\hline Overlay Slump & $\mathrm{K}$ & & & $\mathrm{N}$ & $\mathrm{M}$ & PIW \\
\hline Admixtures & $\mathrm{K}$ & & $\mathrm{N}$ & & $\mathbf{P}$ & IWM \\
\hline \multicolumn{7}{|l|}{ Construction } \\
\hline $\begin{array}{l}\text { Temperature at Deck Placement - } \\
\text { - high temp. deck placements increase cracking } \\
\text { - low temp. deck placements increase cracking } \\
\text { - large temp. changes increase deck cracking } \\
\text { - time of casting }\end{array}$ & 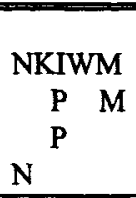 & $\begin{array}{l}\mathrm{N} \\
\mathrm{NK}\end{array}$ & $\mathbf{M}$ & & $\mathrm{K}$ & $\begin{array}{c}\text { P } \\
\text { PI } \\
\text { PI } \\
\text { KPIWM }\end{array}$ \\
\hline Curing Practices & $\mathrm{N}$ W M & & & & $\overline{\mathrm{K}}$ & $\overline{P I}$ \\
\hline Placement Length & $\mathrm{K} \mathrm{W}$ & & & & & N PI M \\
\hline Wind Velocity & & & $\mathrm{N}$ & $\mathbf{K}$ & & PIWM \\
\hline Relative Humidity & $\mathrm{W}$ & & $\mathrm{N}$ & $\mathrm{K}$ & & PI $\quad \mathbf{M}$ \\
\hline Construction Live Loads & $\mathrm{W}$ & & $\mathrm{N}$ & & & KPI M \\
\hline
\end{tabular}
N - HCHRP
I - ICOM
K - K-TRAN
W - WisDOT
$P$ - PennDOT
M - UMN 
Table 2 Typical documentation presented per bridge [after (Eppers et al. 1998)]

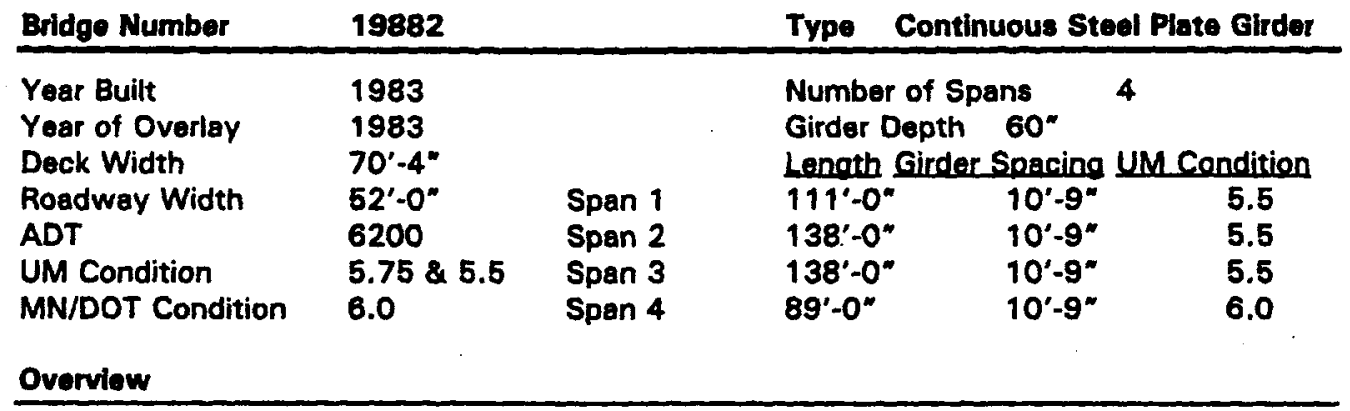

Bridge \#19882 was a two way, two lane bridge over 35E at Blackhawk Road in Eagan.

The skew of all supports was $45^{\circ}$. There was a concrete parapet on an $11^{\prime}-2^{\prime \prime}$ sidewalk on the west side of the bridge and a concrete parapet on a $7^{\prime}-2^{\prime \prime}$ sidewalk on the east side of the bridge. The bridge had staggered steel diaphragms perpendicular to the bridge deck.

Observations

\section{Observations from bottom crack pattem:}

Cracks were observed on spans 1 and 2 at approximately 1-5' spacing. The cracks were observed both at the support and across the midspan, uniformly distributed over the deck.

No bottom bridge deck inspection was conducted.

Observations from top crack pattem:

Cracks were observed to be regularly spaced at approximately 1'-6" to 3'-0" the entire length of the bridge. Most of the cracks were less than $15^{\prime}$ long.

The longest cracks were observed over the piers.

Summary of Contributing and Noncontributing Factors:

\begin{tabular}{|l|c|c|l|c|c|}
\hline Parameter (design) & Contr. & Non. & Parameter & Contr. & Non. \\
\hline Transverse top bar size-spacing & \#6 @ 7" & & Temp. at deck pour & & \\
\hline Transverse top area of steel & - & - & Inventory rating & 23 & \\
\hline Longitudinal top bar size-spacing & & \#4 @18" & Operating rating & 39 & \\
\hline Beam spacing/span length & .078 & & ADT & 6200 & \\
\hline Shear stud type & & & Year built & - & - \\
\hline Deck thickness & & $91 / 4^{\prime \prime}$ & Bar coating & epoxy & \\
\hline Cover & & $3^{\prime \prime}$ & Staged construetion & & \\
\hline Skewed trans. reinforcement & & & Curved bridge & & no \\
\hline Intermediate diaphragm type & & bent plate & Beta (midspan) & - & - \\
\hline Intermed diaphragm aligmment & staggered & & EI/L (multi. span) & - & - \\
\hline
\end{tabular}


Table 2 (cont.) Typical documentation presented per bridge [after (Eppers et al. 1998)]

\begin{tabular}{llll} 
Bridge Number & 19882 & & 401 \\
\hline Year Built & 1983 & Number of Spans & 4 \\
Year Overlaid & 1983 & Length (ft.) & 478.8 \\
Deck Width (ft.) & 70.3 & & \\
Roadway Width (ft.) & 52 & State Project Number & $1982--51$ \\
ADT & 6200 & County & DAKOTA \\
Inventory Rating & 23 & Road Number & 35E \\
Operating Rating & 39 & Road Type & DIVIDED RDWY \\
UMN Condition & 5.6 & Feature Crossed & UNDER BLACKHAWK RD \\
MN/DOT Condition & 6 & Location & 1.5 MI NE OF JCT TH 77 \\
CONSTRUCTION & & & \\
\hline
\end{tabular}

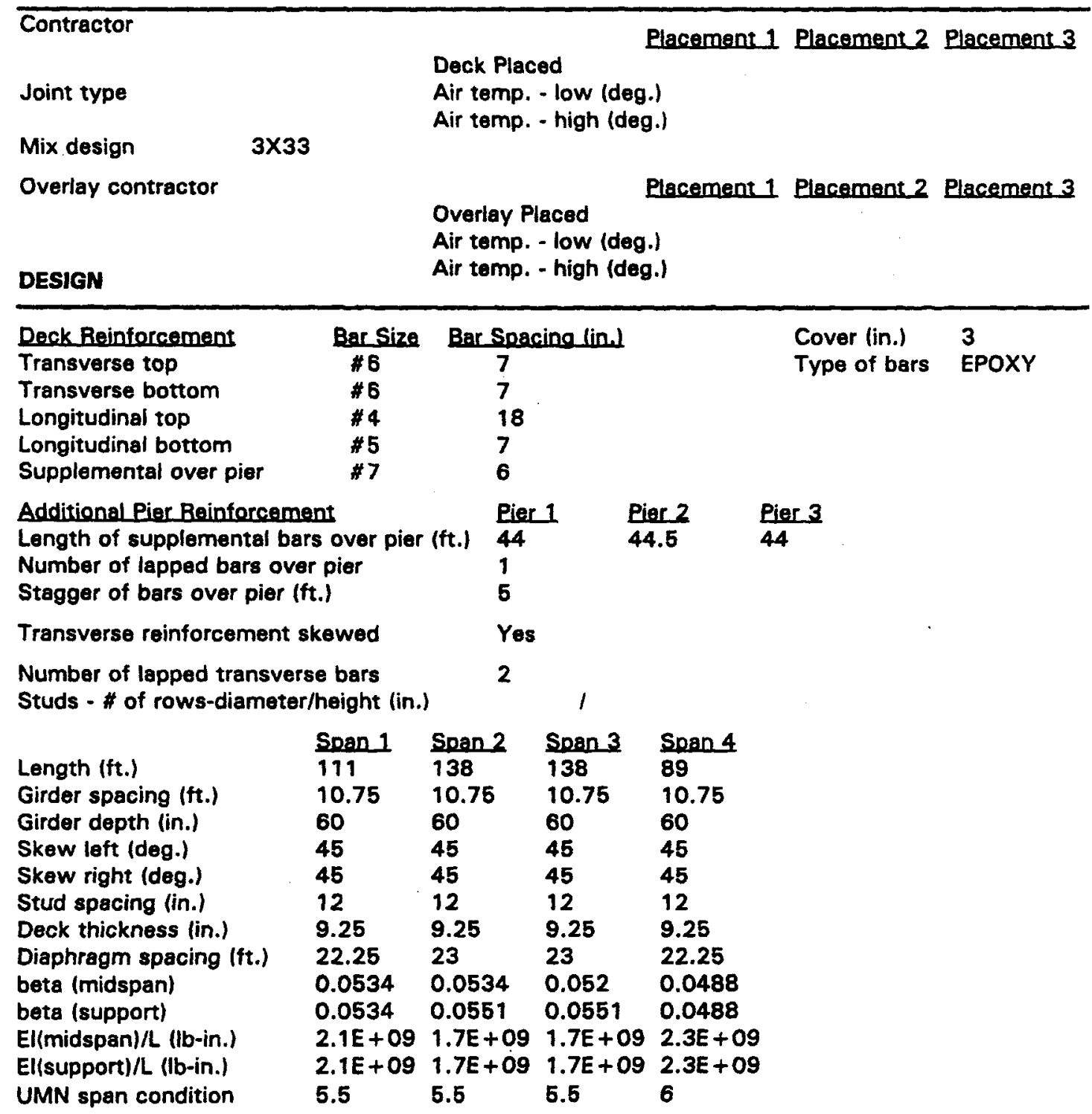


Table 3 UMN concrete bridge deck water and cement content data

\begin{tabular}{|l|c|c|c|c|}
\hline $\begin{array}{c}\text { Cement } \\
\text { content } \\
\text { category }\end{array}$ & $\begin{array}{c}\text { Cement content } \\
\left(\mathbf{N} / \mathbf{m}^{3}\right)\end{array}$ & $\begin{array}{c}\text { Water content } \\
\left(\mathbf{N} / \mathbf{m}^{3}\right)\end{array}$ & W/C ratio & Bridge condition ratings \\
\hline \hline Prestressed Concrete Girder Bridges \\
\hline Low & $3,587-3,761$ & $1,523-1,657$ & $0.42-0.44$ & $9,9,9,9$ \\
\hline Moderate & $3,907-3,912$ & $1,523-1,599$ & $0.39-0.41$ & $7.6,8,8.1,9$ \\
\hline High & $4,000-4,028$ & $1,645-1,663$ & 0.41 & $6.8,8.5,9,9$ \\
\hline \hline Steel Girder Bridges & 3,762 & 1,657 & 0.44 & $6.5(\# 27856), 8$ \\
\hline Low & 3,820 & 1,477 & 0.38 & 8 \\
\hline Moderate & 3,907 & 1,523 & 0.39 & $6(\# 27789)$ \\
\cline { 2 - 6 } & $4,017-4,029$ & $1,657-1,663$ & 0.41 & $6,6.3,7.3,7.5,7.8$ \\
\hline High & & & \\
\hline
\end{tabular}


Table 4 Parametric study of steel bridge girder (Base case: Bridge 62888)

\begin{tabular}{|c|c|c|}
\hline Parameters & $\begin{array}{c}\text { Assumptions of Base Case } \\
\text { Analysis } \\
\end{array}$ & Range of Variations of Parameters ${ }^{2}$ \\
\hline Bridge dimensions & $\begin{array}{l}\text { Dimensions of girder of } \\
\text { Bridge } 62888\end{array}$ & No variation \\
\hline Loading & Composite girder self weight & No variation \\
\hline $\begin{array}{l}\text { Timeline for desk } \\
\text { casting }\end{array}$ & $\begin{array}{l}\text { Timeline causing highest } \\
\text { tensile stresses }\end{array}$ & No variation \\
\hline End conditions & Fixed-roller (2-span) & $\begin{array}{l}\text { Fixed-fixed (continuous span) } \\
\text { Fixed-roller (2-span) } \\
\text { Pin-roller (simply-supported) }\end{array}$ \\
\hline Girder Stiffness & $\mathrm{I}_{\text {girder }}$ of Bridge 62888 & $45 \%, 75 \%$ of $\mathrm{I}_{\text {girder }}$ \\
\hline Cross frames & None & $\begin{array}{l}5 \text { along length unstaggered } \\
11 \text { along length staggered }\end{array}$ \\
\hline Splices & None & $\begin{array}{c}20,25,35 \% \text { of length, resulting in } 185 \% \text { increase in } \\
\mathrm{I}_{\text {girder }} \text { towards fixed support }\end{array}$ \\
\hline $\begin{array}{l}\text { Supplemental steel } \\
\text { bar cutoff length }\end{array}$ & $\begin{array}{l}\text { Bars cutoff at } 10 \% \text { of span } \\
\text { length, staggered }\end{array}$ & $\begin{array}{l}23 \text { to } 44 \% \text { of span length, either staggered or } \\
\text { unstaggered }\end{array}$ \\
\hline Shrinkage curve & ACI 209 shrinkage curve & Upper and lower bound curves from shrinkage tests \\
\hline Deck modulus, $\mathbf{E}_{c}$ & $\mathrm{E}_{\mathrm{c}}$ of bridge 62888 & $55 \%$ of $E_{c}$ \\
\hline $\begin{array}{l}\text { Temp. differential: } \\
\text { heat of hydration } \\
\text { and girder preheat }\end{array}$ & $\begin{array}{l}\text { Constant ambient } \\
\text { temperature }\end{array}$ & $\begin{array}{l}\text { - Deck cooled moderately due to heat of hydration } \\
\text { - Deck cooled extensively due to heat of hydration } \\
\text { - Girder preheated moderately and deck and girder } \\
\text { then cooled by same amount } \\
\text { - Girder preheated extensively and deck and girder } \\
\text { then cooled to same temperature }\end{array}$ \\
\hline Creep of concrete & Active & No variation \\
\hline Aging of concrete & Active & No variation \\
\hline
\end{tabular}

${ }^{a}$ Most parameters were varied as shown for all three end fixity conditions; selected parameters were not varied for certain end fixity conditions (6) 


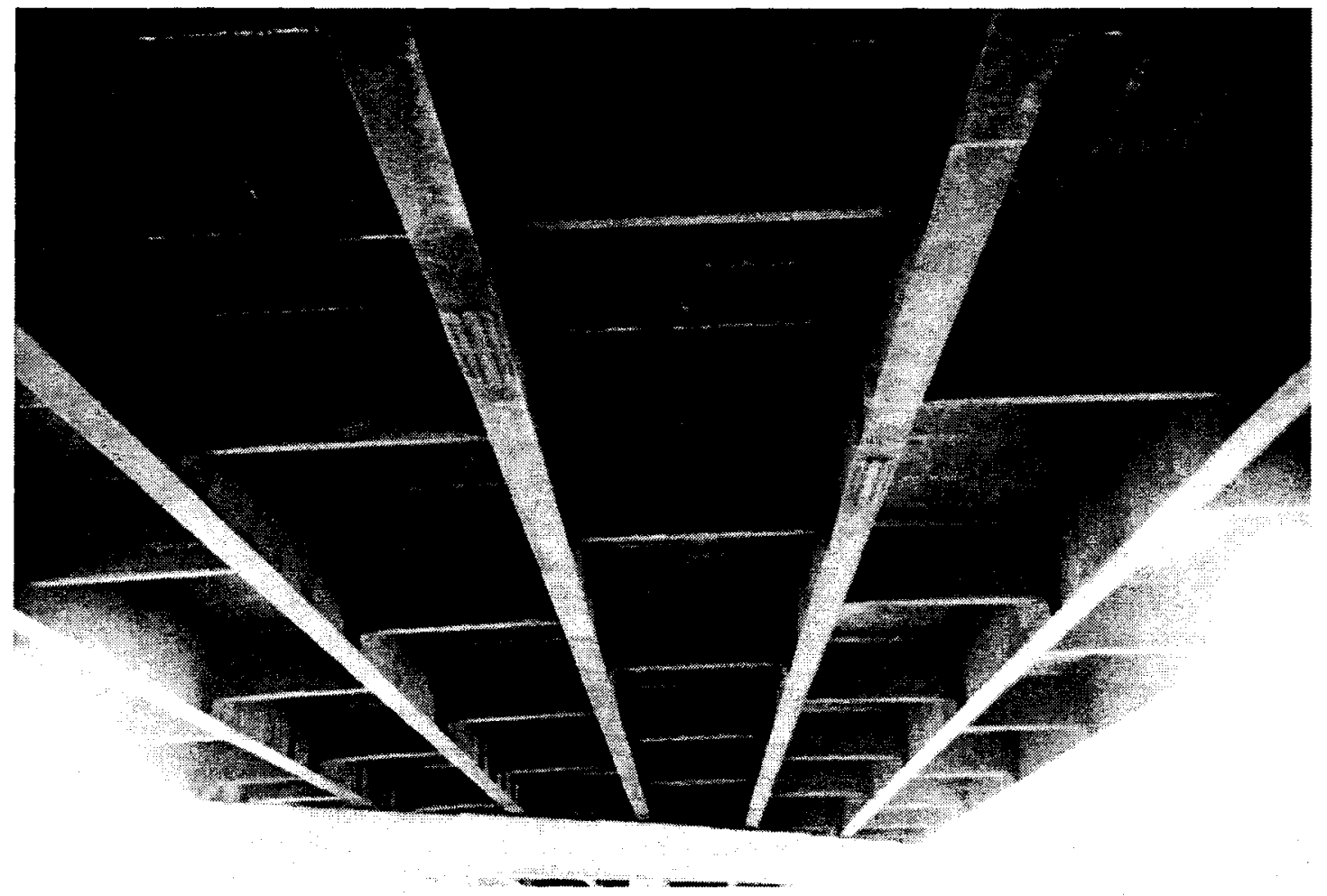

Figure 1 Bridge No. 19882: Span 2, looking north, showing cracking on bottom of deck [after (Eppers et al. 1998)] 


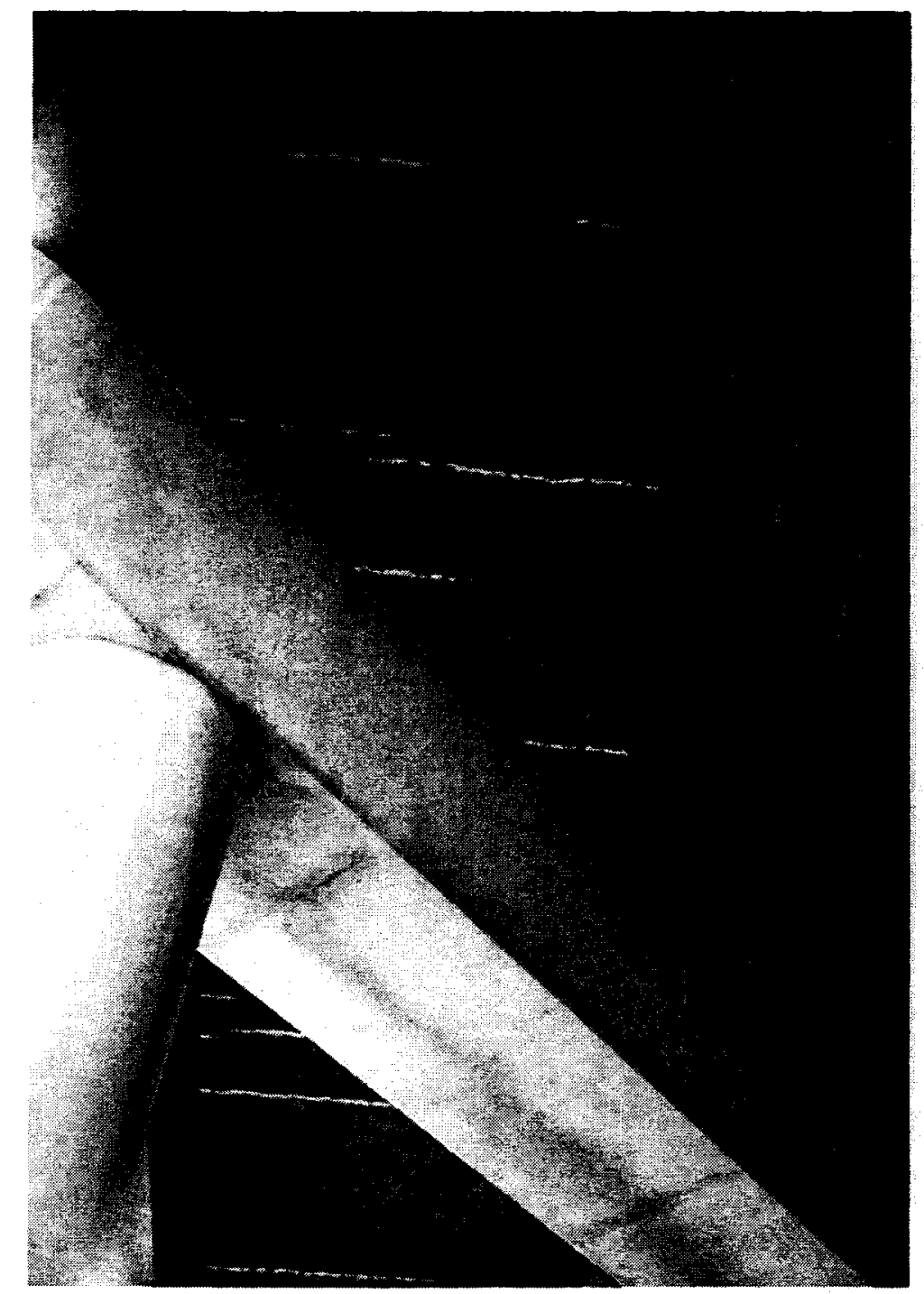

Figure 2 Bridge No. 19882: Pier 1 at west edge of bridge deck [after (Eppers et al. 1998)] 


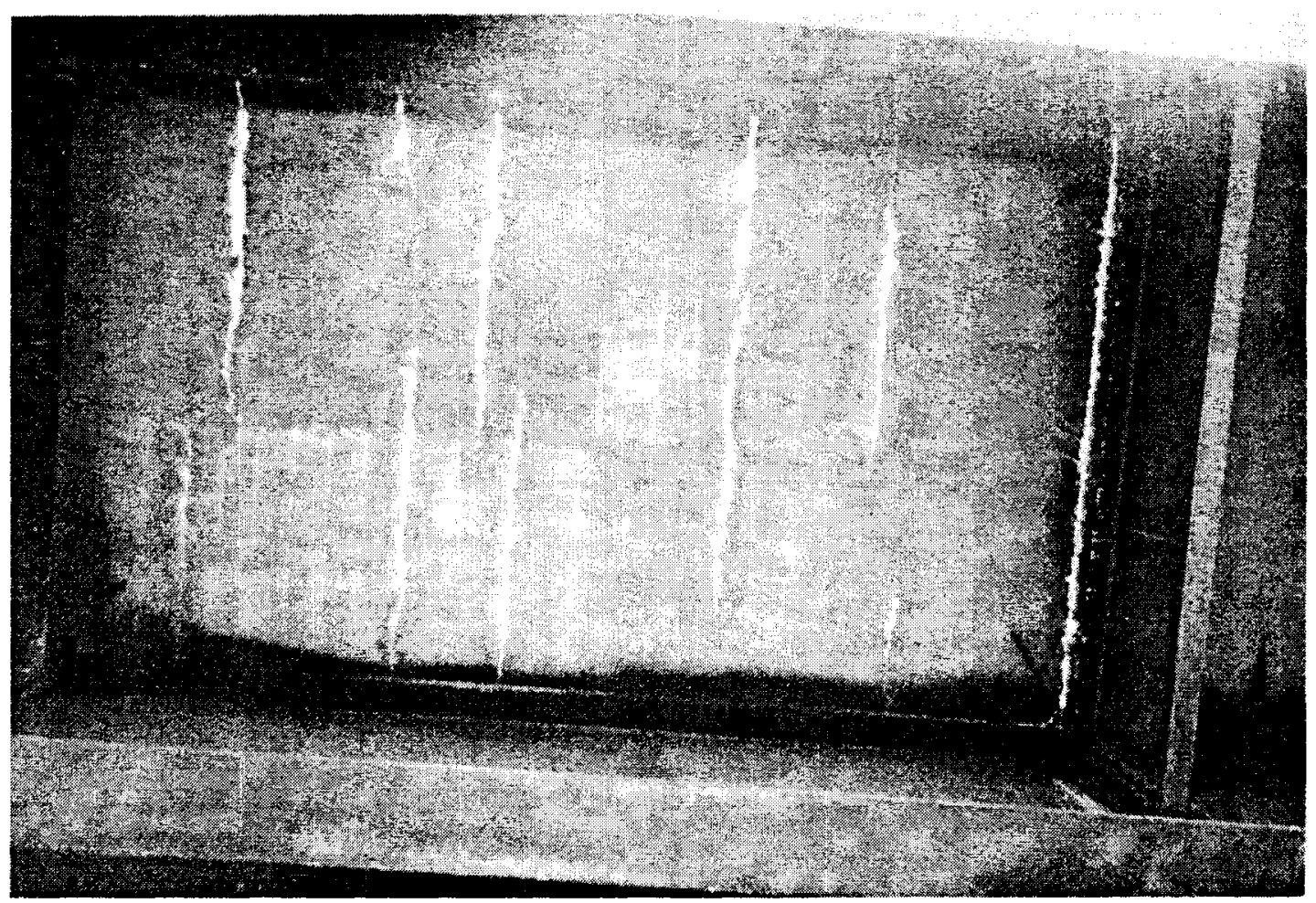

Figure 3 Bridge No. 19882: west edge of bridge deck between pier 1 and first intermediate diaphragm [after (Eppers et al. 1998)] 

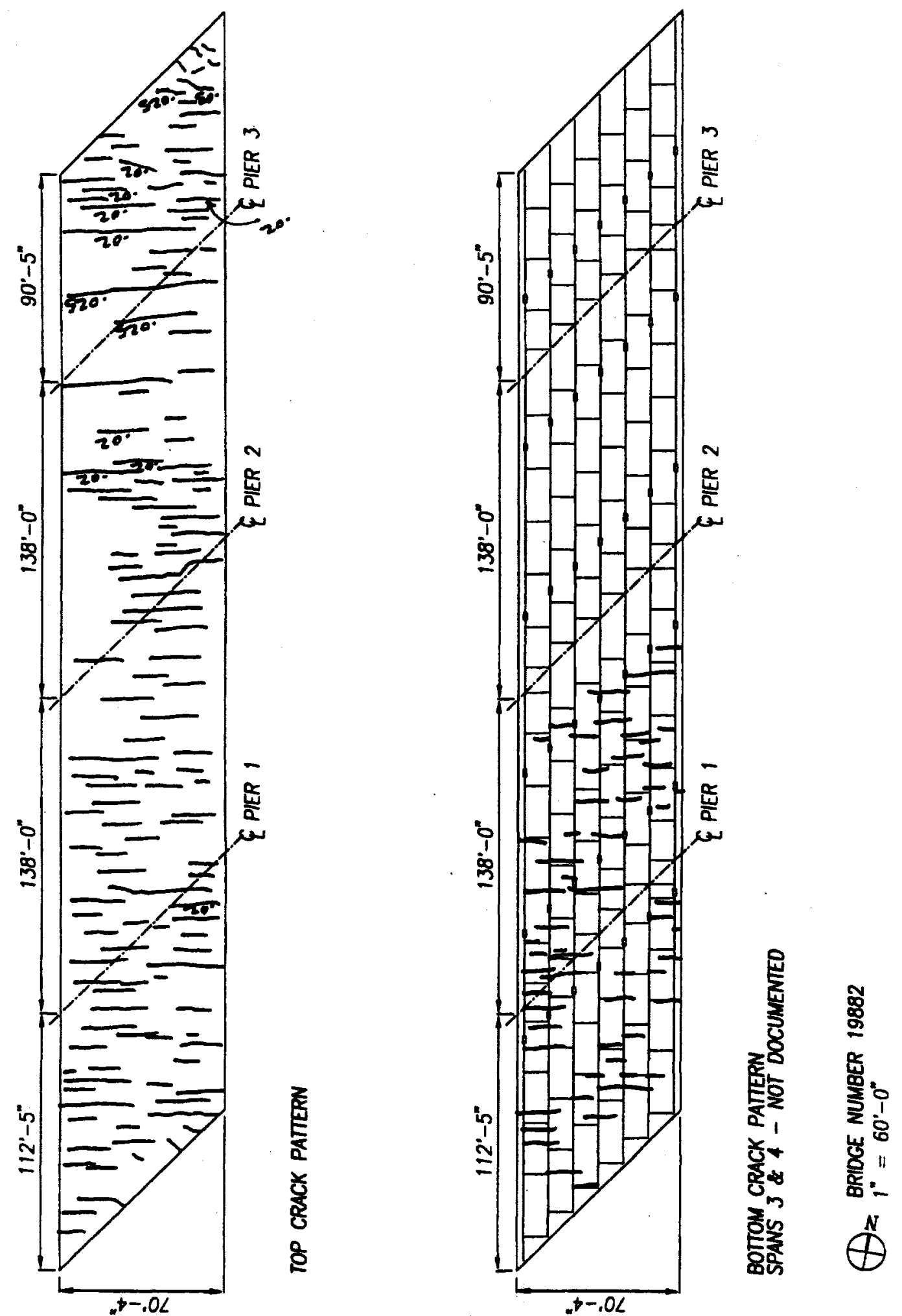

Figure 4 Bridge No. 19882: top and bottom crack patterns [after (Eppers et al. 1998)] 


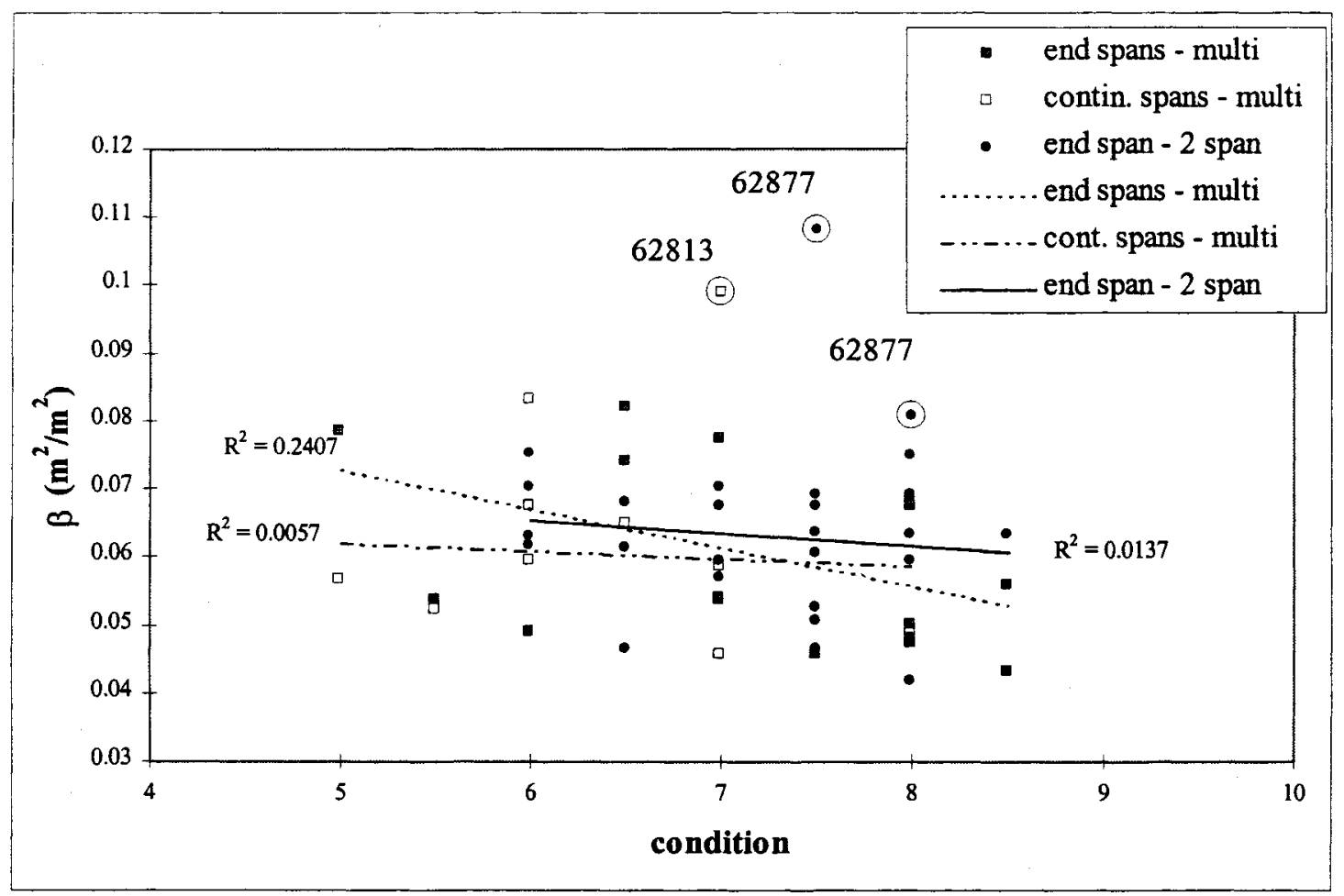

19 end-span multiple-span, 15 continuous-span multiple-span, and 34 two-span bridges

Figure 5 Restraint coefficient beta (at midspan) vs condition: steel girder bridges 


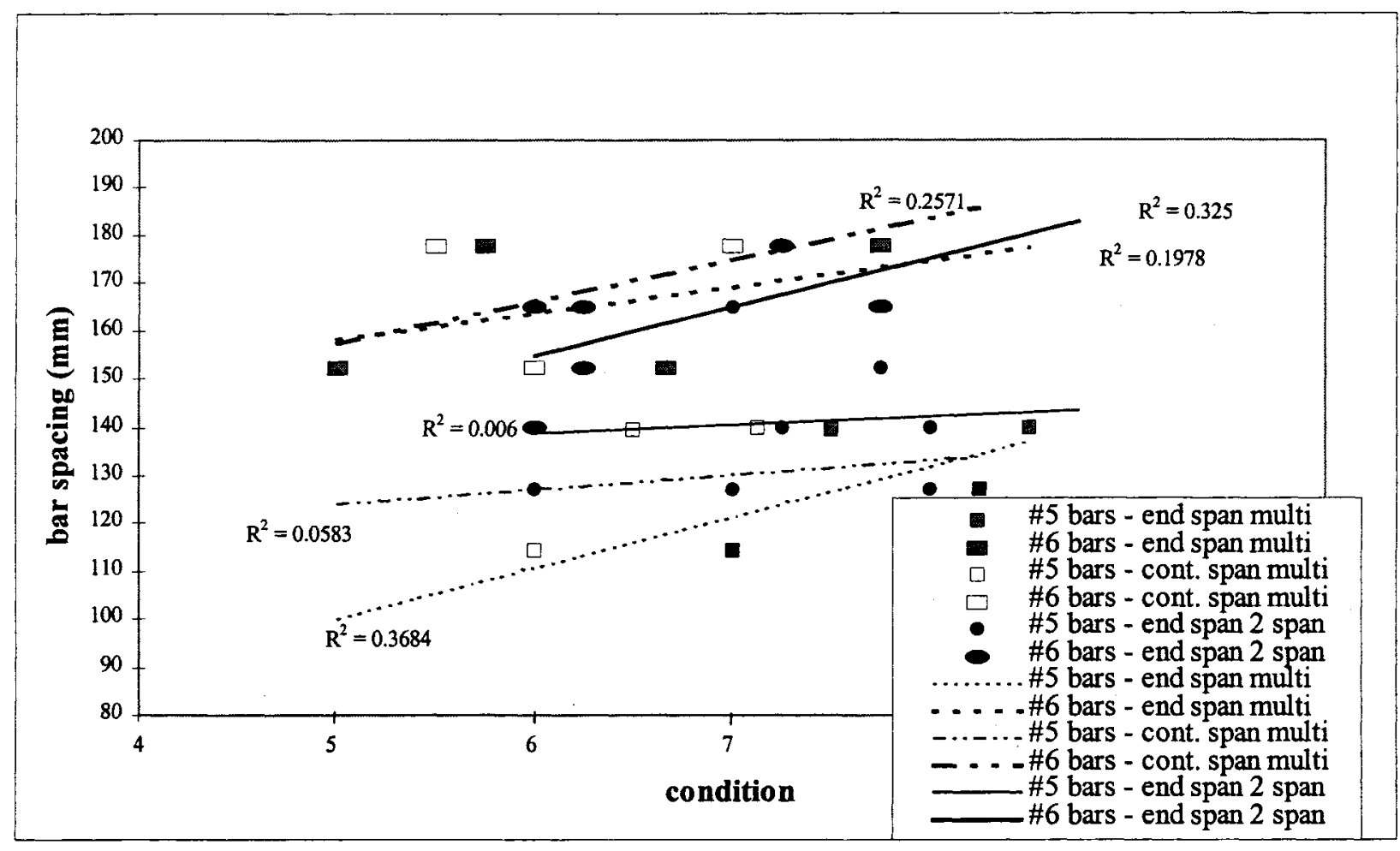

9 multiple-span and 16 two-span bridges

Figure 6 Spacing of top transverse reinforcing bars vs condition: steel girder bridges 


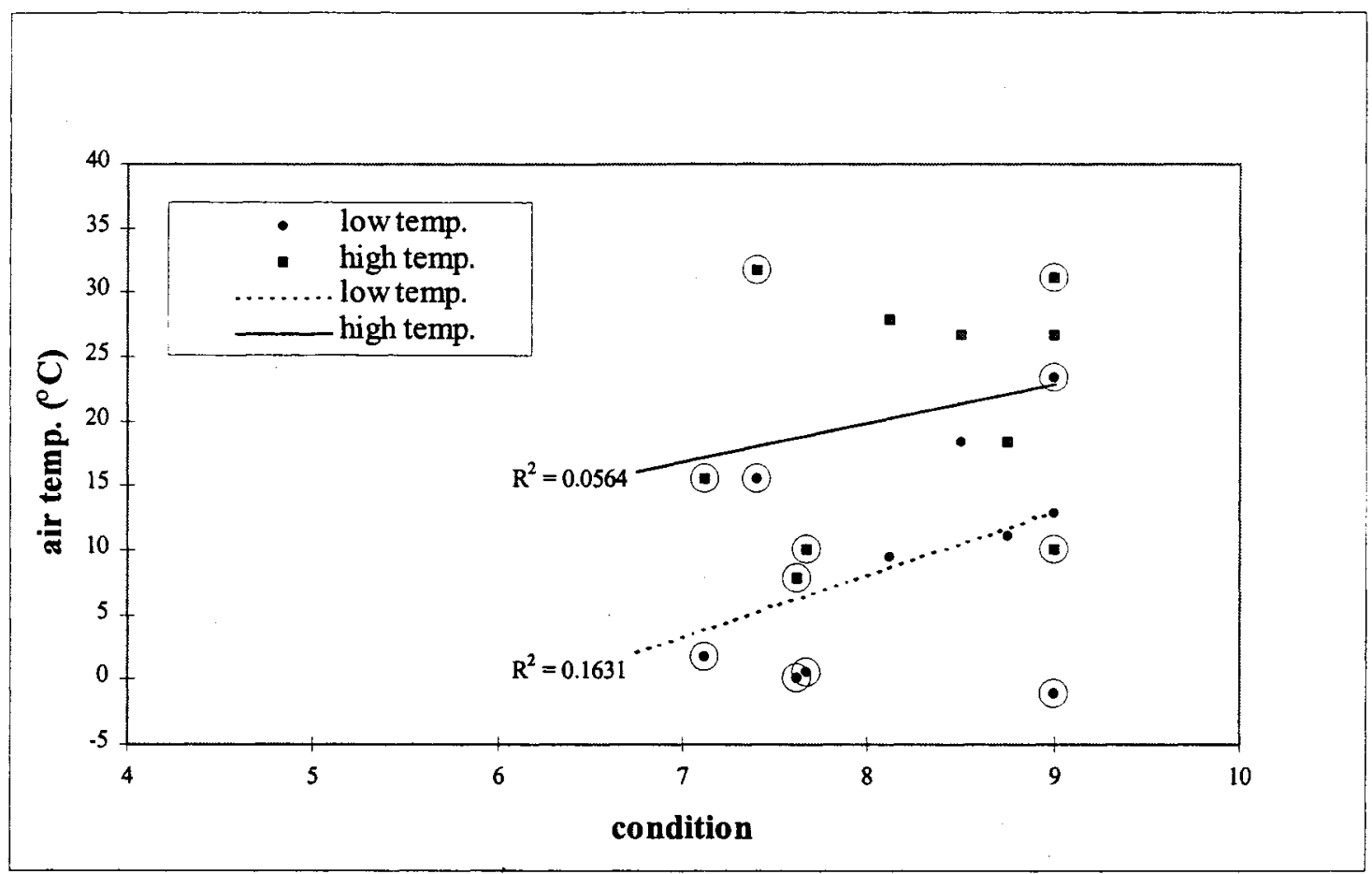

10 bridges

Figure 7 Air temperature at deck placement versus condition: prestressed girder bridges 


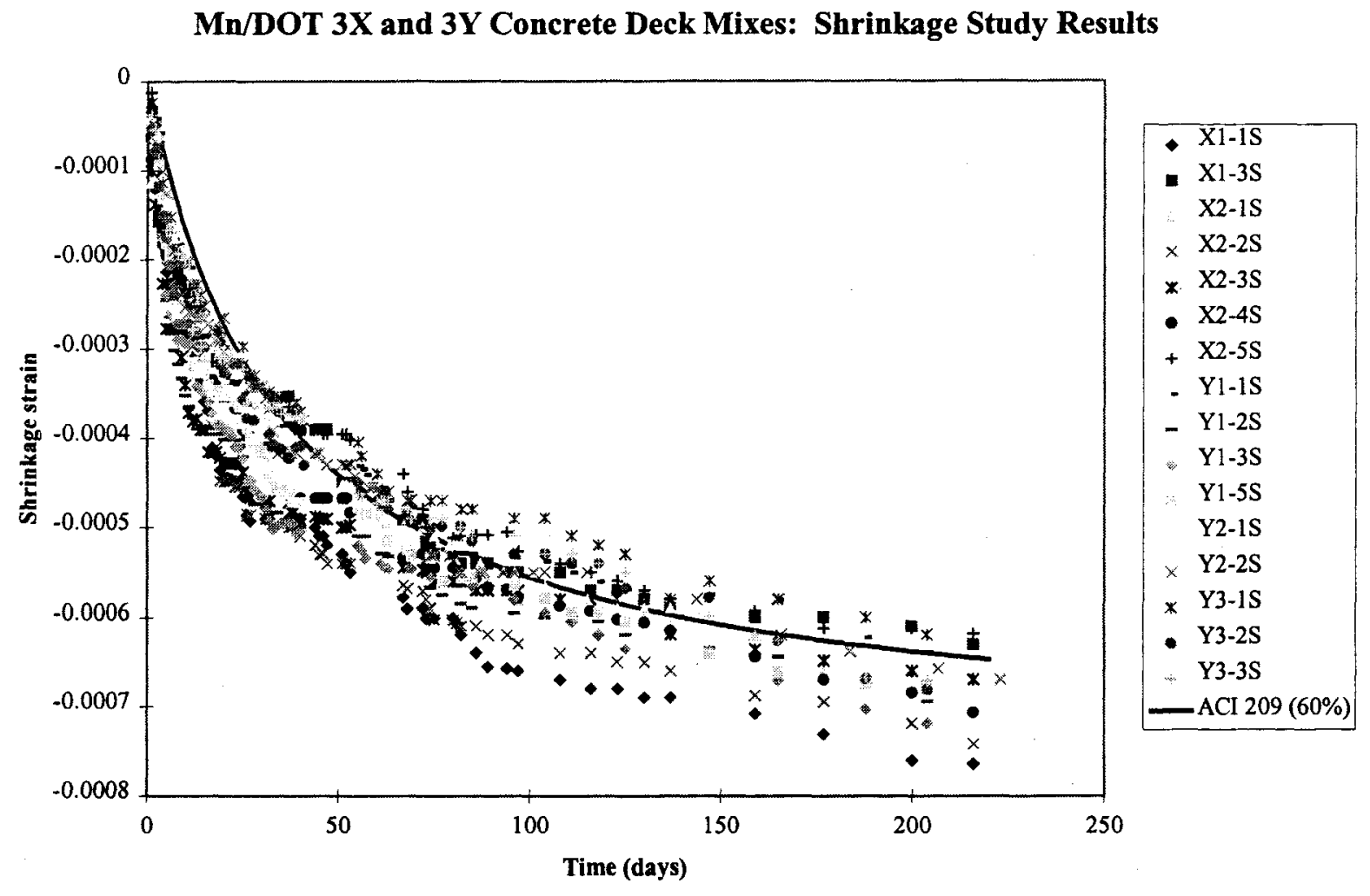

Figure 8 Shrinkage Data for Mn/DOT 3X and 3Y Concrete Bridge Deck Mixes 

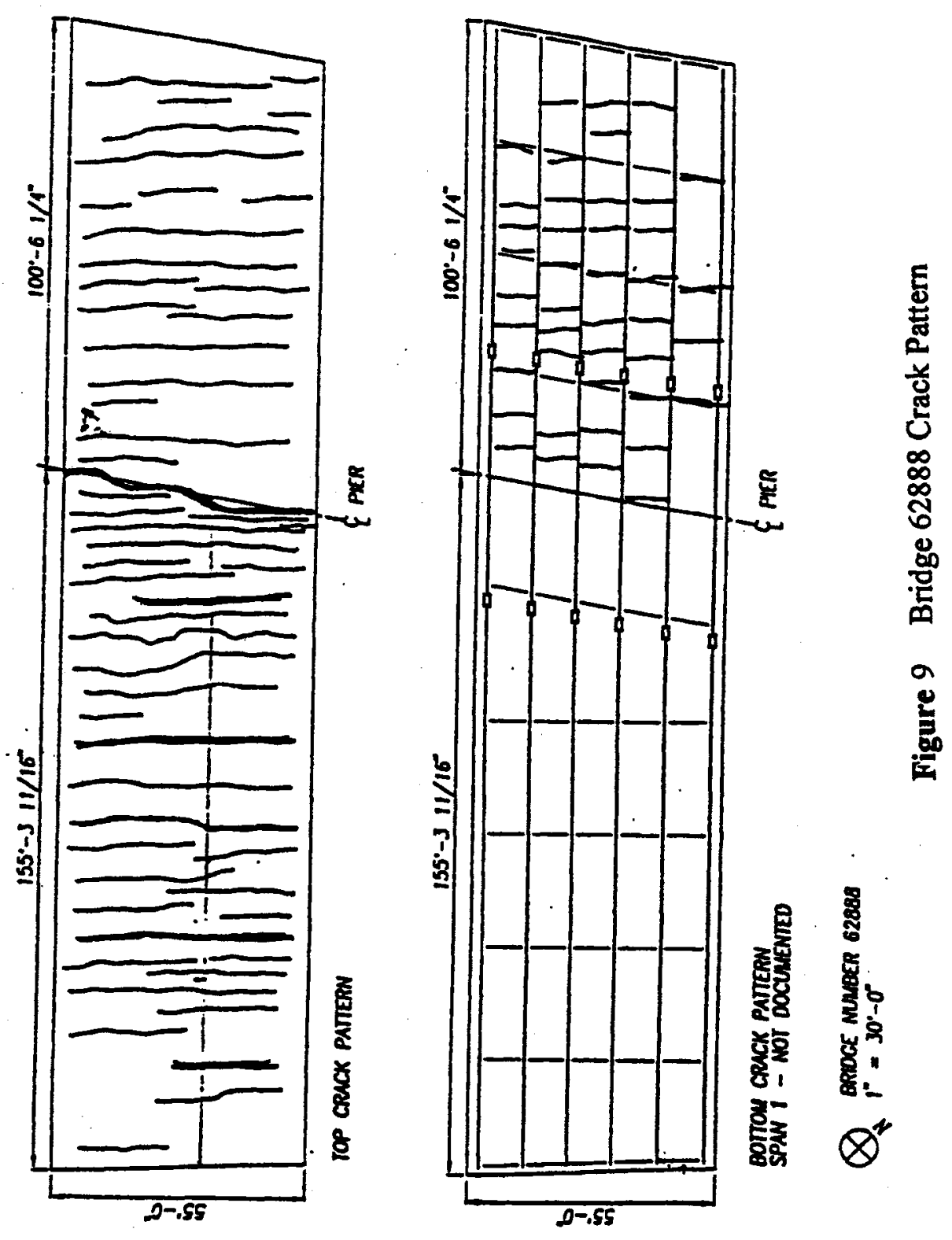
